Universidade de Brasília - UnB

Instituto de Ciências Humanas - IH

Departamento de Serviço Social - SER

Maria Estela Dias Argolo

ADOÇÃO DE CRIANÇAS E ADOLESCENTES EM SITUAÇÃO DE ABRIGAMENTO: A ÚLTIMA OU A ÚNICA ALTERNATIVA?

Brasília 
MARIA ESTELA DIAS ARGOLO

\title{
ADOÇÃO DE CRIANÇAS E ADOLESCENTES EM SITUAÇÃO DE ABRIGAMENTO: A ÚLTIMA OU A ÚNICA ALTERNATIVA?
}

\begin{abstract}
Trabalho de Conclusão do Curso de graduação em Serviço Social sob a orientação da Professora Doutora Potyara Amazoneida Pereira Pereira para obtenção do grau de Assistente Social.
\end{abstract}

Brasília (DF), dezembro de 2007. 


\section{ADOÇÃO DE CRIANÇAS E ADOLESCENTES EM SITUAÇÃO DE} ABRIGAMENTO: A ÚLTIMA OU A ÚNICA ALTERNATIVA?

Banca Examinadora

Prof. ${ }^{a}$ Dr. ${ }^{a}$ Potyara Amazoneida Pereira Pereira

(Presidente)

Prof. Dr. Perci Coelho

Prof. ${ }^{a}$ Msc. Patrícia Cristina Pinheiro

Brasília, 14 de dezembro de 2007 
DEDICATÓRIA

As mulheres da minha vida: minha nona, Maria Honória; minhas filhas, Thais e Gisele;

minhas mães, Adelayde, biológica, e Therezinha, adotiva.

Ao meu esposo, Edil, companheiro, amigo, amor. 


\section{Agradeço sinceramente}

A Deus, pela certeza de sua presença, seu poder, sua misericórdia e seu amor incondicional na minha vida.

A todos os meus familiares, em especial à minha Nona materna, que me adotou ainda bebê, que me incentivou na arte de aprender, minha flor amada, que, onde quer que esteja, deve estar orgulhosa de mim.

À minha mãe, tia ou mãe adotiva, às minhas filhas e ao meu esposo pelo incentivo, pela compreensão e pelo respeito às minhas opções.

À minha orientadora Professora Doutora Potyara Amazoneida Pereira Pereira por aceitar tão difícil tarefa.

À minha filha Jamila Zgiet, a quem adotei de coração durante a realização do Curso de Serviço Social e que esteve comigo nos momentos mais importantes da graduação e da elaboração deste trabalho.

Ao Excelentíssimo Senhor Juiz Titular da Vara da Infância e da Juventude do DF, Dr. Renato Rodovalho Scussel, e à Coordenadora de Projetos Institucionais, Dra. Thais Botelho, por terem autorizado a pesquisa processual sobre adoção de crianças e adolescentes em medida de abrigamento no Distrito Federal.

Às supervisoras de estágio da Seção de Adoção, Viviane Faleiro e Lucineide Bastos, e ao supervisor Walter Gomes, com quem muito aprendi, pela generosidade, compreensão, carinho e confiança depositados.

Aos professores e às professoras do Departamento de Serviço Social, em especial Denise Bomtempo, Patrícia Pinheiro, Nair Bicalho, Luiz Fernando Viegas, Perci Coelho e Evilásio Salvador e à professora do departamento de Letras, Ellen Crista da Silva, pelo carinho e amizade.

Às colegas do Programa de Educação Tutorial, Jamila Zgiet, Thais Imperatori, Elen Martins, Michele Lago, Josiellen Resende, Kelly Barbi, Ana Flávia Marques, Isabella Vieira, Natália Gonçalves, Priscila Nolasco, Regiane Rodrigues, Geucilene Vieira, Anie Carvalho, Thalita Santos e Marina Leite, que me ensinaram a trabalhar em grupo e a respeitar diferentes opiniões.

Aos meus amigos e colegas de estágio, Heloiza Pinto, Márcia Lima, Alice Gomes, Miriã Nogueira, Ana Lúcia Mendes, Eliane Cristina Resende, Márcia Jeane, Niva Maria 
Campos, Luciana Peregrinelle, Valeska Marinho, Viviane Costa, Daniele Carreiro, Maria Carolina e Siméia Feitosa por compartilhar conhecimentos e experiências e concordarem em participar da pesquisa.

Às colegas da turma de 2005 do curso de Serviço Social, que me receberam carinhosamente e se tornaram minhas grandes amigas.

Aos funcionários do Departamento de Serviço Social, Rafael, Angélica e Domingas, pela atenção e carinho com que me atendiam.

Enfim...

... a todos que acreditaram neste sonho, ajudando-me de alguma forma a concretizá-lo. 
Você tem sede de quê?

Você tem fome de quê?

a gente não quer só comida,

a gente quer comida, diversão e arte.

a gente não quer só comida,

a gente quer saída para qualquer parte

(...)

a gente quer bebida, diversão, balé.

a gente não quer só comida,

a gente quer a vida como a vida quer.

a gente não quer só comer,

a gente quer comer e quer fazer amor.

a gente não quer só comer,

a gente quer prazer pra aliviar a dor.

a gente não quer só dinheiro,

a gente quer dinheiro e felicidade.

a gente não quer só dinheiro,

a gente quer inteiro e não pela metade.

(Arnaldo Antunes, Marcelo Frommer e Sérgio Britto) 
Resumo: As dificuldades encontradas pelas famílias pobres para cuidar e educar seus filhos fizeram com que elas os abandonassem cada vez mais. A desigualdade social que prevaleceu no país desde o período colonial se expressou até mesmo nos direitos formalmente estabelecidos, categorizando diferentemente os filhos da elite e os dos pobres - o que só veio a ser rompido com o Estatuto da Criança e do Adolescente (ECA), de 1990, e com a Lei de Diretrizes e Bases da Educação, de 1996. Ainda assim, as ações e políticas disponíveis de atendimento à família são fragmentadas e praticamente inexistentes. A proteção à família, inscrita na Constituição Federal vigente, promulgada em 1988, é algo ainda a ser concretizado. Apesar do aspecto financeiro não ser legalmente motivo para a perda ou suspensão do poder familiar, nota-se que um número considerável de famílias se vê pressionado a abandonar seus filhos em instituições de abrigo como estratégia de sobrevivência - para si e para a própria criança - devido a sua crítica situação econômico-financeira. Para melhor compreender as razões que levaram a Vara da Infância e da Juventude (VIJ/DF) a cadastrar para adoção crianças e adolescentes abrigados, num período de 4 meses, em 2007, foram realizadas entrevistas estruturadas com 5 (cinco) profissionais das instituições de abrigo do DF; com 10 (dez) técnicos da Seção de Adoção e analisados os documentos de 10 processos de crianças e adolescentes cadastrados para adoção na VIJ/DF. Estabeleceram-se como hipóteses, que se confirmaram: a) as famílias não encontram alternativas para cuidar de seus filhos, que não a adoção; b) os abrigos não trabalham a reintegração dessas crianças à família de origem; c) os profissionais do judiciário tendem a ver na adoção a única possibilidade de crianças e adolescentes acessarem a convivência familiar, já que a maioria destes vem de famílias que se encontram abaixo da linha da pobreza. Dos resultados, destacam-se os seguintes fatos: a família biológica apresenta a carência material como motivo para o abrigamento de seus filhos; o trabalho da instituição de abrigo para reestruturar a família e reintegrar seus filhos é falho; os profissionais da Seção de Adoção percebem que, na maioria das vezes, a adoção é a única alternativa da criança e do adolescente estar numa família como filho.

Palavras-chave: crianças e adolescentes na perspectiva do ECA; abandono, abrigo; adoção; pobreza; direitos de cidadania. 


\section{Lista de siglas}

CEUB - Centro Universitário de Brasília

COMPP - Centro de Orientação Médico Psicopedagógica

CRAS - Centro de Referência da Assistência Social

ECA - Estatuto da Criança e do Adolescente

HUB - Hospital Universitário de Brasília

IBDFam - Instituto Brasileiro de Direito da Família

ONG - Organização Não Governamental

SESC - Serviço Social do Comércio

SEDEST - Secretaria de Estado de Desenvolvimento Social e Trabalho

SESI - Serviço Social da Indústria

UCB - Universidade Católica de Brasília

UNIP - Universidade Paulista

VIJ/DF - Vara da Infância e da Juventude do Distrito Federal

\section{Lista de Quadros}

Quadro 1 - Perfil das entidades de abrigo pesquisadas (p.37)

Quadro 2 - Perfil das crianças e dos adolescentes pesquisados (p.37) 


\section{SUMÁRIO}

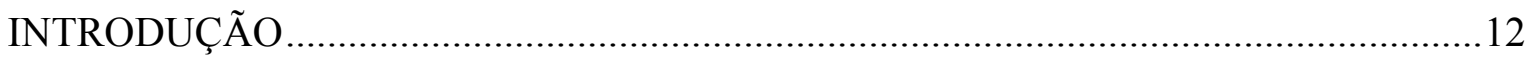

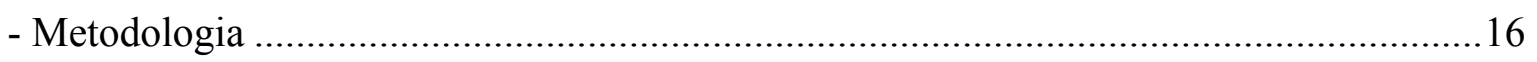

CAPÍTULO I - ASPECTOS HISTÓRICOS DO ABANDONO, DA

INSTITUCIONALIZAÇÃO E DA ADOÇÃO DE CRIANÇAS E ADOLESCENTES

1.1. A Construção social da infância e da família ................................................................19

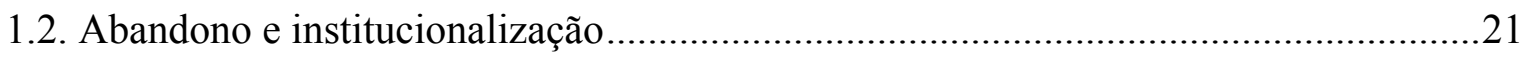

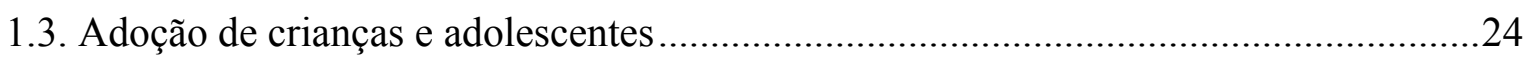

CAPÍTULO II - APRESENTANDO A VARA DA INFÂNCIA E DA JUVENTUDE

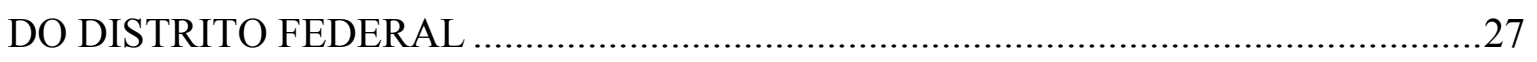

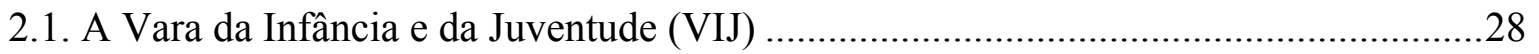

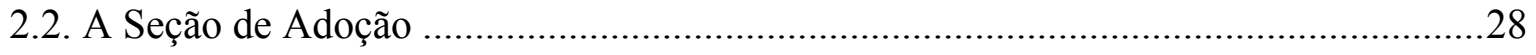

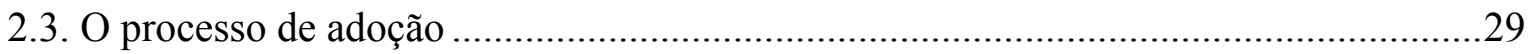

2.4. O Serviço Social da Seção de Adoção ........................................................................... 34

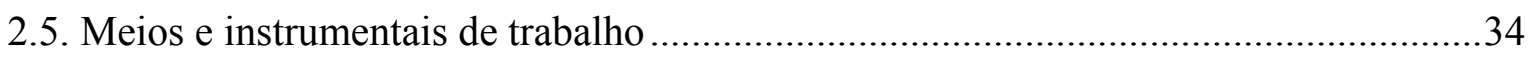

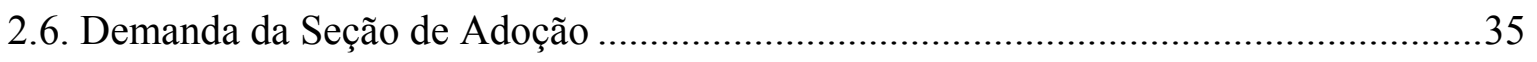

CAPÍTULO III - APRESENTANDO AS INSTITUIÇÕES DE ABRIGAMENTO...........36

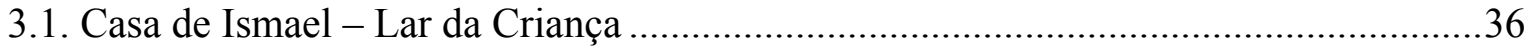

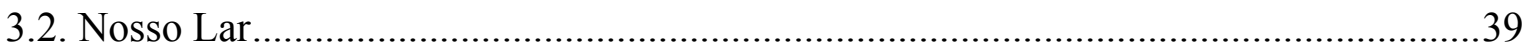

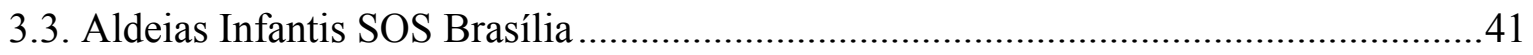

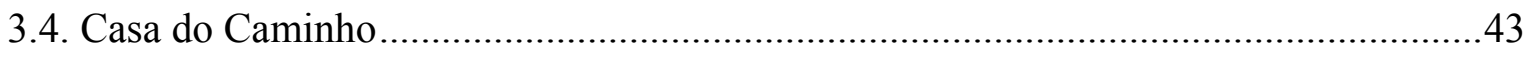

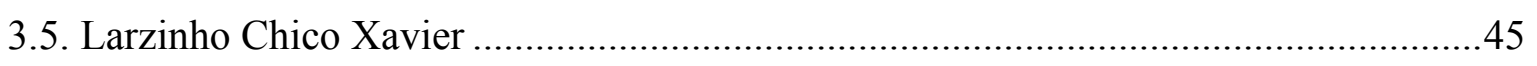

CAPÍTULO IV - ANÁLISE DOS DADOS COLETADOS NA PESQUISA DE

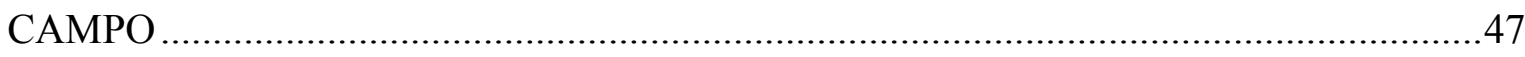

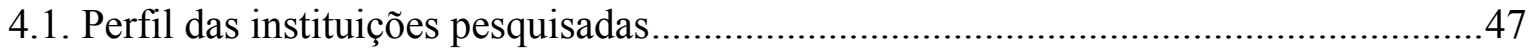

4.2. Perfil das crianças e dos adolescentes cadastrados para adoção ....................................48

4.3. Motivos que levaram ao abrigamento de crianças e adolescentes..............................49

4.4. Tentativas de reintegração familiar por parte das instituições de abrigo ......................52

4.5. Recursos para a convivência comunitária das crianças e dos adolescentes ..................55 
4.6. A percepção dos técnicos judiciários quanto ao papel da adoção no acesso à convivência familiar

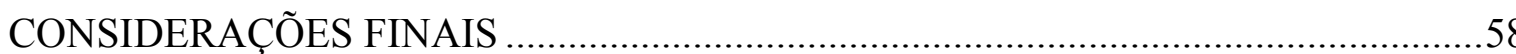

REFERÊNCIAS BIBLIOGRÁFICAS

\section{APÊNDICES}

- Apêndice A - Roteiro semi-estruturado de entrevista realizada com assistentes sociais e psicóloga dos abrigos pesquisados

- Apêndice B - Roteiro semi-estruturado de entrevista realizada com assistentes sociais e psicólogas da Seção de Adoção da Vara da Infância e da Juventude do Distrito Federal

- Apêndice $\mathrm{C}$ - Ficha de coleta de dados das pastas especiais

- Apêndice D - Termo de Consentimento Livre e Esclarecido

ANEXO

- Anexo A - Cópia do documento procedimento de autorização à realização da pesquisa na Seção de Adoção da Vara da Infância e da Juventude do Distrito Federal 


\section{INTRODUÇÃO}

Abordar o tema "adoção" é tarefa difícil, pois se sabe que esse processo é quase sempre precedido de uma história de abandono, especialmente no Brasil onde grande parte da população encontra-se marginalizada por um modelo econômico historicamente concentrador de rendas, injusto e desigual.

A motivação para realizar este estudo surgiu da observação da realidade de famílias e crianças/adolescentes acompanhados por meio de visitas domiciliares, visitas às instituições de abrigo e entrevistas pelo período de dezoito meses de estágio curricular na Seção de Adoção da VIJ/DF.

De acordo com informações obtidas na Vara da Infância e da Juventude do Distrito Federal (VIJ/DF), em 44,3\% do total de casos de adoção ocorridos em 2005, o motivo apresentado para a entrega da criança era a falta de condições financeiras e/ou materiais. Apesar do aspecto financeiro não ser legalmente motivo para a perda ou suspensão do poder familiar, nota-se, a partir dos dados apresentados, que um número considerável de famílias se vê pressionado a abandonar seus filhos em instituições de abrigo como estratégia de sobrevivência (para si e para a própria criança) devido a sua crítica situação econômico-financeira.

Como afirma Oliveira (2002), muitos abrigos têm, em seu Estatuto, a finalidade de oferecer um lar às crianças sem família. Entretanto, no cotidiano dessas instituições prevalece uma realidade diferente de sua proposição formal, visto que a maioria das crianças e adolescentes abrigados tem família, mas em situação sócio-econômica precária, que impede a convivência familiar saudável. Vê-se, assim, que, por trás da problemática do abrigamento - que tende a se tornar regra - existe a realidade da extrema pobreza, que é cada vez mais grave e vivenciada por parcelas expressivas da população brasileira. Sem direito ao trabalho, à moradia, à alimentação, à creche, à saúde, ou seja, sem políticas públicas efetivas e comprometidas com a melhoria das condições de vida e de cidadania das famílias pobres, estas, em geral representadas e sustentadas apenas pela genitora, acabam vendo no abrigamento de seus filhos - crianças e adolescentes - a saída possível.

Com base nesse quadro, foi estabelecida, a partir dessa problematização, a pergunta principal a ser respondida por esta pesquisa: "quais as razões de fundo que levam a Vara da 
Infância e da Juventude do Distrito Federal a cadastrar para adoção crianças e adolescentes que se encontram em situação de abrigamento?’.

Partindo dessa realidade, em que se circunscreve o problema desta investigação, foi eleito como objeto de estudo as razões que levam a Vara da Infância e da Juventude do Distrito Federal a cadastrar para adoção crianças e adolescentes que se encontram abrigadas.

Esta pesquisa teve como objetivo geral conhecer e identificar os principais fatores que levaram ao abrigamento de crianças e adolescentes e ao cadastramento destes para adoção.

Os objetivos específicos da pesquisa consistiram em:

a) identificar aspectos no âmbito da família biológica que levaram ao abrigamento da criança ou do adolescente;

b) verificar quais os procedimentos realizados pela instituição de abrigo com vista a reestruturação da família, possibilitando a reintegração, nesta, da criança ou do adolescente abrigado;

c) conhecer a percepção dos profissionais da Seção de Adoção em relação à reintegração da criança ou do adolescente na família de origem.

Com o conhecimento prévio dos fatores que induziram ao cadastramento de crianças e adolescentes para adoção - sejam eles familiares, institucionais e sociais acreditou-se poder, com esta pesquisa, colaborar com informações para o processo de elaboração de procedimentos não só compatíveis com a lei, mas também com as legítimas demandas e necessidades dos sujeitos envolvidos. Procurou-se, assim, construir um conjunto de conhecimentos sobre a prática desenvolvida no processo de abrigamento e adoção, seja no contexto do poder judiciário, da instituição de abrigo, seja de qualquer outro meio que possa permitir às famílias em questão o acesso a procedimentos de sua reestruturação, a fim de que consigam resgatar seus filhos num breve espaço de tempo.

Nesse processo de conhecimento que, no fundo, justifica a realização da presente pesquisa, observaram-se dificuldades de várias ordens a respeito da compreensão da preservação ou resgate dos vínculos familiares. Um desses dificultadores é a recusa de parlamentares em implementar as medidas previstas no Estatuto da Criança e do Adolescente (ECA), levando-os a um pensamento deturpado quanto à posição que a família 
ocupa no desenvolvimento da criança e do adolescente e quanto ao impacto do abandono, em decorrência do abrigamento e da adoção para os mesmos.

A esse respeito tomou-se conhecimento, por meio da mídia, que o deputado João Matos, em 20 de agosto de 2003, colocou em pauta o Projeto de Lei nº 1756/03, que está em análise na Câmara Federal, propondo a Lei Nacional da Adoção. Esse Projeto de Lei ignora o princípio da proteção integral às crianças e adolescentes ao propor uma redução do tempo de abrigamento, possibilitando um cadastramento precoce para adoção, uma vez que seria facilitada a destituição do poder familiar. Isto demonstra uma tentativa de legitimar uma tendência que está se tornando hegemônica nas práticas cotidianas das instituições de abrigo e também na sociedade.

Segundo notícia veiculada pelo jornal Correio Braziliense, em 14 de outubro de 2007, outro projeto polêmico foi discutido no mês de novembro/2007, na capital mineira, tratando da criação da lei do parto anônimo. Se aprovado, tal procedimento permitirá que a mulher dê a luz na Maternidade, sem precisar se identificar ou assumir qualquer responsabilidade legal pelo filho. De acordo com o advogado Rodrigo da Cunha, representante do Instituto Brasileiro de Direito da Família (IBDFam), o objetivo desse Projeto de Lei é o de tentar resolver, pela adoção simplificada, as formas trágicas do abandono que vêm acontecendo nos últimos dias no Brasil. Hércules Barros, também do referido jornal, afirmou que essa prática já é adotada em países como Bélgica, França e Itália e que ela procura evitar situações extremas, como aborto e abandono do recémnascido pela mãe.

Esses fatos indicam a dificuldade, não só da sociedade, mas também dos legisladores, em lidar com os direitos da criança e do adolescente e de conhecer mais a fundo a sua legitimidade e indisponibilidade. Significam trazer de volta um procedimento medieval, tão discutido no passado, que foi a "roda dos expostos ou enjeitados", na qual eram depositados anonimamente recém-nascidos para adoção. O parto anônimo, como considera a procuradora do estado de São Paulo, Flávia Piovezan, viola o direito de livre escolha da mulher, além de negar o nome dos pais biológicos ao nascituro, ferindo um direito civil básico, previsto na Constituição Federal vigente, que é "o direito à identidade".

No que tange à orientação teórica, a pesquisa se baseou num referencial coerente com as categorias analíticas que compõem o eixo conceitual do trabalho, a saber: crianças e 
adolescentes na perspectiva do ECA; abandono, abrigamento e adoção; pobreza e direitos de cidadania. Em torno dessas categorias foram escolhidos autores cujo enfoque teóricoconceitual respalda a perspectiva da cidadania no processo de abrigamento e adoção de crianças e adolescentes.

No primeiro capítulo, apresenta-se um histórico sobre a construção social da infância e da família a partir do século XVI. Discute-se a questão do abandono e da institucionalização de crianças e adolescentes no Brasil, além de como se dá a adoção de crianças e adolescentes segundo a legislação brasileira.

O segundo capítulo contém a apresentação da Vara da Infância e da Juventude do Distrito Federal e da Seção de Adoção, um dos campos da pesquisa, destacando-se o trabalho das assistentes sociais, os instrumentais utilizados pela equipe para a realização do trabalho e a demanda atendida pela Seção.

O terceiro capítulo trata da sistematização do conteúdo das entrevistas realizadas com assistentes sociais e uma psicóloga, de cinco instituições de abrigamento selecionadas no Distrito Federal e também do conteúdo das entrevistas realizadas com os profissionais da Seção de Adoção da VIJ/DF.

O quarto e último capítulo, traz as conclusões obtidas na análise das entrevistas com as profissionais das instituições de abrigo do DF, bem como com as da Seção de Adoção da VIJ/DF, e no estudo das "pastas especiais" de cinco crianças e cinco adolescentes residentes nos abrigos considerados. Essas conclusões abordam o perfil das instituições pesquisadas; os motivos que levaram, ao abrigamento, crianças e adolescentes; as tentativas de reintegração familiar por parte das instituições de abrigo; os recursos disponíveis para a convivência comunitária das crianças e adolescentes e a percepção dos técnicos do Judiciário quanto ao papel da adoção no acesso à convivência familiar.

Esta pesquisa procurou acrescentar elementos de reflexão ao debate sobre a importância da aplicação da lei em compatibilidade com os direitos dos sujeitos envolvidos. Visou ainda reforçar a idéia de que o sistema de garantias de proteção básica às famílias seja, em sua inteireza, colocado em prática pelas autoridades brasileiras. Essa questão tem se apresentado como um desafio para o Serviço Social, na medida em que exige do profissional dessa área maior conhecimento das redes institucionais de apoio e proteção 
social às famílias ou às genitoras, que precisam acessar programas que melhorem as suas condições de vida e de cidadania.

\section{Metodologia}

A investigação privilegiou a metodologia qualitativa, utilizando técnicas de coleta e análise qualitativa de dados, como a entrevista semi-estruturada, a análise do discurso, e a análise de documentos, ou seja, técnicas que de alguma forma privilegiaram o uso da palavra para descrever o fenômeno observado, um fato humano-social. Os dados quantitativos disponibilizados na estatística e em documentos do judiciário foram utilizados para complementar a análise qualitativa. (MUCHIELELLI, 1991).

Muchielelli (1991) enfatiza que as técnicas qualitativas de coleta de dados em geral colocam o pesquisador numa posição particular em relação ao objeto de sua pesquisa, à própria pesquisa e às pessoas com quem vai trabalhar. Ou seja, permitem o estudo de um fenômeno para que se alcance o conhecimento do porque e do como do objeto de estudo, geralmente com vista a uma intervenção transformadora.

Segundo Minayo (1992;1994), a abordagem metodológica que se utiliza na investigação de um fenômeno deve harmonizar-se com o tipo de situação que se deseja estudar e com as questões originadas pela pesquisa. A autora afirma que a pesquisa em ciências humanas e sociais, dadas às particularidades de delimitação de seus objetos, se beneficia das abordagens qualitativas.

O estudo também se baseou no método dialético para analisar os dados levantados. O método dialético fundamenta-se na dialética prevista, inicialmente, por Hegel, na qual as contradições se superam dando origem a novas contradições que requerem solução. É um método interpretativo dinâmico e totalizante da realidade, pois considera que os fatos não podem ser considerados fora de um contexto histórico, social, político e econômico. É um método que contempla pesquisa qualitativa. (GIL, 1999; LAKATOS; MARCONI, 1993).

Para fins de organização e divisão do trabalho, dividiu-se a pesquisa em quatro fases. Primeiramente, em julho de 2007, procurou-se realizar uma revisão de literatura sobre as categorias analíticas que constituem o eixo conceitual do trabalho, para fundamentação teórica da pesquisa. 
$\mathrm{Na}$ segunda fase, em agosto de 2007, os dados foram coletados por meio de entrevistas semi-estruturadas com as assistentes sociais das instituições de abrigo do DF Casa de Ismael, a qual possuía o maior número (31) de crianças e adolescentes cadastrados para adoção, seguido do Nosso Lar e Aldeias Infantis SOS (ambas com 21), Casa do Caminho (18) e Larzinho Chico Xavier (9).

$\mathrm{Na}$ terceira fase, em setembro de 2007, coletaram-se dados quantitativos e qualitativos contidos nas estatísticas elaboradas pela VIJ/DF, que também foi fonte de informações sobre crianças e adolescentes abrigados e cadastrados para adoção, dados esses disponíveis em processos numerados que cada criança ou adolescente possui na VIJ/DF e que são denominados "pastas especiais".

$\mathrm{Na}$ quarta fase, em outubro de 2007, os dados foram coletados por meio de entrevistas semi-estruturadas com dez técnicas (sete psicólogas e três assistentes sociais) da Seção de Adoção da VIJ/DF. Estas trabalham no atendimento a famílias ou genitoras que se apresentam ao serviço de plantão para entregar seu/sua filho/a para adoção, realizam estudos psicossociais de Adoção e de Inscrição, bem como seleção e preparação de candidatos.

O critério de seleção dos participantes da Seção de Adoção foi o de que as técnicas tivessem pelo menos seis meses de atividade no referido Setor, tempo necessário para que elas estivessem mais envolvidas com a discussão sobre a situação familiar das crianças e dos adolescentes encaminhados para adoção.

Para escolha dos abrigos, observou-se a existência de profissionais prioritariamente de Serviço Social ou, na inexistência destes, de Psicologia no quadro de servidores. Outro critério foi o maior número de crianças e adolescentes cadastrados para adoção.

Quanto à utilização das pastas especiais, foram selecionados aleatoriamente dois documentos de crianças e adolescentes de cada instituição de abrigo, sendo um de criança (até 12 anos) e outro de adolescente (de 13 até 17 anos) abrigados na instituição. O objetivo foi conhecer sua situação em duas fases diferentes e também observar a idade com que foram abrigados.

Como instrumentos para coleta de dados foram utilizados dois roteiros de entrevista semi-estruturados, sendo que um teve como público-alvo as assistentes sociais e a psicóloga da instituição de abrigamento (Apêndice A) e o outro esteve voltado para as 
profissionais da Seção de Adoção (Apêndice B). Utilizou-se ainda uma ficha de registro contendo as categorias e aspectos que mais interessavam ao estudo das pastas especiais (Apêndice C). Esses roteiros abordaram principalmente: os motivos que levaram ao cadastramento da criança ou do adolescente para adoção; o trabalho realizado pela instituição de abrigo que visasse à reintegração familiar; e a percepção dos técnicos judiciários quanto ao papel da adoção no acesso à convivência familiar. 


\section{Capítulo I}

\section{ASPECTOS HISTÓRICOS DO ABANDONO, DA INSTITUCIONALIZAÇÃO E DA ADOÇÃO DE CRIANÇAS E ADOLESCENTES}

\subsection{A Construção Social da Infância e da Família}

A idéia da infância como um período peculiar de nossas vidas não é um sentimento natural ou inerente à condição humana. A "aparição da infância" foi construída gradativamente a partir do século XVI, quando a família conjugal (pai, mãe, filho, avós), formada por poucos integrantes, se fortaleceu. Isso aconteceu, principalmente, com o surgimento do mercantilismo, quando se alteraram o sentimento e as relações frente à infância, modificados conforme a estrutura social (ARIÈS, 1981).

Segundo Ariès (ibidem), o reconhecimento da infância surgiu com as famílias nobres francesas que podiam oferecer saúde, educação e melhores cuidados aos seus filhos. O grupo dos pobres não exerceu o sentimento da infância, pois encontrou limites econômico-culturais no âmbito familiar. Essas condições fizeram com que seus filhos, desde cedo, ocupassem o mundo dos adultos, seja por meio do trabalho, do exército ou do casamento.

A Igreja e o Estado, representados por moralistas e educadores, também contribuíram para uma nova consciência em relação à infância, embora com uma função prática - ora de disciplinar, ora de proporcionar conhecimentos técnicos - o que, mais tarde, produziu uma escola para elite e outra para o povo (ARIÈS, 1981).

De acordo com Badinter (1985), foi no século XVIII, na Europa, que começou a preocupação com a higiene e a saúde física das crianças, inspirada pelas ações médicas. Até então, os médicos não tratavam as crianças, pois consideravam que essa tarefa “desnecessária” não era digna. Só em 1872 surgiu a designação específica do campo da pediatria.

No Brasil, a medicina higienista teve início no século XIX, seja pelo contato entre brasileiros e europeus, que vieram para o país como cientistas e ocuparam cargos em nossas 
instituições, seja por estudantes brasileiros que fizeram curso de especialização na Europa (PORTO, 1985).

Influenciados pelos europeus, os higienistas brasileiros investiram na família de elite e burguesa, com o objetivo de modificar os hábitos anti-higiênicos coloniais. A higiene enfocava a educação física, moral, intelectual e sexual (COSTA, 1979).

Durante o século XIX, a ciência passou a perceber a infância e a adolescência como fases específicas do desenvolvimento humano, tornando-as objeto de estudo da pediatria, da puericultura, da psicologia e da pedagogia (ARIÈS, 1981; RIZZINI, 1993).

Trindade (1999) afirma que, no Brasil, os higienistas preocupavam-se em explicar às famílias brancas como combater a mortalidade infantil. Era visível a diferença no tratamento das crianças brancas e das negras. Também havia diferenciação entre os sexos. No entanto, a morte atingia crianças sem distinção e, naturalmente, mais as isentas de cuidados.

Segundo Trindade (ibidem), quando as crianças nasciam eram entregues às amasde-leite para que fossem criadas, pois consideravam que essa era uma forma de garantir sua sobrevivência. As crianças eram levadas para a casa dessas amas e só retornavam à família de origem após cinco anos de idade, quando sobreviviam às diversas dificuldades.

As amas, mal alimentadas e consumidas pelo trabalho nas roças, tinham a oferecer a essas crianças um leite de baixa qualidade. Existiam também alguns pais que preferiam outro tipo de alimentação para seus filhos, apesar de grosseira ao estomago delicado da criança, pois acreditavam que a ama pudesse passar o seu caráter à criança através do leite. (TRINDADE, 1999)

Muitas amas-de-leite, com o objetivo de calar o choro incômodo da criança, lhe aplicavam narcóticos, cujo excesso era fatal. A sujeira e a falta de higiene contribuíam para a morte precoce. As amas-de-leite eram camponesas, escravas ou ainda mães solteiras, abandonadas na miséria, que deixavam seus filhos em instituições e ganhavam um salário para servir como nutrizes das crianças dos ricos (BADINTER, 1985).

Segundo Civiletti (1991), até o final do século XIX, para justificar a grande mortalidade infantil comparavam-se as crianças mortas aos anjos. Dessa forma, minimizava-se a repercussão da morte e evitava-se o longo sofrimento, relacionando a criança àquele que não possui pecado. 


\subsection{Abandono e institucionalização}

No contexto brasileiro do século XVIII do período colonial até a crise do Império, as crianças abandonadas eram chamadas "expostas" e "enjeitadas". Essas crianças, recémnascidas, eram colocadas em locais onde certamente seriam recolhidas, como igrejas e conventos. Mais tarde, o mecanismo adotado para tal função foram as chamadas "rodas dos expostos" (TRINDADE, 1999).

A "roda dos expostos", de origem medieval e italiana, inicialmente utilizada para manter os monges reclusos, correspondia a um sistema com dispositivo giratório de madeira, semelhante a uma caixa cilíndrica, que girava sobre um eixo vertical e dispunha de uma janela para acolher a criança na instituição, sem que o depositante fosse identificado (MARCÍLIO, 1998; MOTTA, 2001; VENÂNCIO, 1999)

Segundo Trindade (1999), o sistema da roda foi instalado no Brasil a partir do século XVIII - a primeira na Bahia e, depois, no Rio de Janeiro e em São Paulo. As instituições pensadas para acolher e assistir os abandonados, transformaram-se em agências para eliminar a infância indesejada.

A roda dos expostos, instalada e mantida pelas Santas Casas de Misericórdia, era também a única saída para aquelas mães que não conseguiam cuidar de seus filhos. As escravas encontravam na roda a possibilidade de salvar da escravidão seus filhos recémnascidos (CIVILETTI, 1991).

A mortalidade nessas instituições também era alta, pois havia carência tanto qualitativa quanto quantitativa de alimentos. Doenças como a gastroenterite, sífilis e infecções gerais eram constantes. As condições de vida em pequenos ou grandes asilos eram precárias. As crianças morriam antes de completar um ano de idade (TRINDADE, 1999).

De acordo com Trindade (ibidem), por volta do século XIX surgiu nova categoria de abandono: o de crianças com mães conhecidas, que tinham nome, sobrenome e domicílio conhecidos. Na tentativa de frear o fluxo crescente desse tipo de abandono, as instituições passaram a exigir das famílias responsáveis, indicações precisas sobre o nascimento. Essa estratégia permitia o recolhimento de crianças legítimas nas instituições de asilo apenas por motivos de doença das mães ou por falta de condições para o 
aleitamento. No entanto, essas medidas, criadas para evitar o abandono, não surtiram o efeito esperado, pois o número de crianças asiladas continuou crescendo.

Segundo o mesmo autor (ibidem), embora a mortalidade dos abandonados fosse alta, certo número sobrevivia aos perigos dos primeiros anos de vida, devido, principalmente, ao aleitamento que as amas-de-leite das instituições proporcionavam. Esses sobreviventes deixavam as instituições para trabalhar ou para casar. Os meninos eram enviados para o trabalho com os artesãos aos dez anos de idade. As meninas, que não casassem, eram colocadas como serviçais nas casas de famílias importantes.

No decorrer do século XIX, novas estratégias foram adotadas, tanto pelo Estado quanto pela Igreja, com o intuito de esvaziar as instituições de asilo. A mãe passou a ser tratada com mais atenção e as famílias foram orientadas a não abandonarem seus filhos. Teve início, assim, uma associação entre a criança, que precisa de proteção e informação, e a família, que tem a missão de proteger e educar (BADINTER, 1985).

As dificuldades encontradas pelas famílias pobres para cuidar e educar seus filhos, fizeram com que elas os abandonassem cada vez mais. As dificuldades culturais, psíquicas, sociais e econômicas vividas pelos jovens, os empurravam para a marginalidade e, até mesmo, para a criminalidade. A partir daí difundiu-se a idéia de que a falta de família estruturada gerava criminosos. Esse fato contribuiu para que o Estado assumisse as tarefas da educação, saúde e punição para crianças e adolescentes infratores (PASSETI, 2006).

Faleiros (2003), em seu texto "Verso e Reverso da Proteção Integral para Crianças e Adolescentes", aborda a questão da negação e da afirmação dos direitos da criança e do adolescente, considerando o processo histórico-social e de construção da legislação para a infância no Brasil. O autor afirma que a desigualdade social que prevaleceu no país desde o período colonial, se expressou até mesmo nos direitos formalmente estabelecidos, categorizando diferentemente os filhos da elite e os dos pobres - o que só veio a ser rompido com o Estatuto da Criança e do Adolescente (ECA), de 1990, e com a Lei de Diretrizes e Bases da Educação, de 1996.

Faleiros salienta ainda que a doutrina liberal de direitos iguais nem sequer se fez presente na história dos direitos infanto-juvenis no Brasil, fazendo com que o marco legal a respeito dessa matéria padecesse de uma "esquizofrenia" ou polarização normativa, com duas vertentes: uma para a elite e, outra, para os pobres. A maioria da população, portanto, 
configurava uma exceção, não constituindo uma prioridade de atendimento e nem sendo alvo de política de inclusão. Dessa forma, conclui Faleiros, a maioria da população não representava regra, e sim a exceção, na definição das políticas sociais.

De acordo com Weber e Kossobudzki (1996), abandonados são as crianças ou os adolescentes não assistidos pela família, que não possuem relação de continuidade com seus familiares, mesmo que estejam em instituição de abrigo.

Nessa condição, ainda hoje se encontram numerosos contingentes de crianças e adolescentes. Isso leva Freire (1991) a afirmar que as ações e políticas disponíveis de atendimento à família são fragmentadas e praticamente inexistentes. Os poucos recursos alocados em políticas compensatórias são dispersos em programas isolados para o idoso, o deficiente, a criança, entre outros. A proteção à família, inscrita na Constituição Federal vigente, promulgada em 1988, é algo ainda a ser concretizado.

A mídia escrita e televisionada tem veiculado com freqüência casos de abandono de recém-nascidos, encontrados flutuando em rios, ou de crianças deixadas em locais públicos. Percebe-se, porém, que essas mães apresentam comportamento de desespero ou patológico. Isso demonstra que, por falta de apoio, seja da família, seja do parceiro ou do Estado, essas mães acabam reproduzindo o abandono pessoal sofrido, abandonando seus filhos.

De acordo com Freire (1991), existem pais negligentes, irresponsáveis, cujo poder familiar de fato deve ser destituído, mas há que se ter um olhar e uma ação especial para a manutenção de vínculos entre crianças e adolescentes e suas famílias. Para tanto, devem-se adotar medidas de prevenção do abandono e de reintegração familiar, com empenho tanto das autoridades competentes como da comunidade, tendo como referência o ECA.

Para Weber (1996), a institucionalização de crianças é um dispositivo que pretende proteger a infância. Mas, na realidade, o que ocorre é simplesmente o afastamento de crianças e adolescentes marginalizados (carentes, abandonados, doentes, infratores) do convívio social. Segundo essa autora (idem), após o internamento - medida que deveria ser tomada como recurso extremo e por curto período - existe probabilidade bastante grande de ocorrência de abandono nas instituições.

Com efeito, a medida de abrigo é excepcional e tem caráter provisório, tendo como objetivo a reintegração social da criança e do adolescente num breve espaço de tempo. Durante a aplicação da medida, há necessidade de se manter os vínculos das crianças e dos 
adolescentes abrigados com seus familiares e de lhes dar apoio para que possam receber seus filhos de volta e consigam mantê-los de forma adequada. Enquanto essas crianças e adolescentes permanecem abrigados, a legislação determina que devem ser realizados esforços para propiciar-lhes o direito à convivência familiar e comunitária segura, quer por meio da colocação em família substituta sob guarda, quer pela colocação em abrigos semelhantes a uma residência, que proporcionem atendimento individualizado $\mathrm{e}$ personalizado. Ressalte-se, ainda, que a criança e o adolescente moradores de abrigo, por melhor que seja este, estão com seu direito de convivência familiar e comunitária violado (IPEA, 2005).

\subsection{Adoção de crianças e adolescentes}

Rastreando a legislação brasileira, observa-se que, de acordo com o Código Civil de 1916, só poderiam ser adotantes pessoas com idade superior a 50 anos, sem filhos legítimos ou legitimados, e com uma diferença de 18 anos entre a sua idade e a do adotado. Tal adoção tinha ainda caráter revogável e não anulava o vínculo com a família biológica. Assim, segundo Fonseca (1995: 120), "a posse da criança era regulamentada no cartório da mesma forma que se regulamentava a posse de bens e imóveis”.

Em 1957 foram promovidas algumas alterações no Código Civil, por meio da Lei n. ${ }^{\circ} 3.133$, que Fonseca (ibidem) compreende como marco do surgimento do interesse pela criança e pelo seu bem-estar. Essa lei reduziu a idade dos adotantes para 30 anos e a diferença de idade entre pais e filhos adotivos passou a ser de 16 anos. No entanto, no que se refere aos direitos sucessórios, não havia ainda igualdade. A filiação era aditiva, isto é, o sobrenome da família biológica não poderia ser substituído pelo da família adotiva, podendo apenas ser acrescentado ao mesmo (FONSECA, 1995; VARGAS, 1998).

Em 1965 a Lei n. 4.655 reconheceu a filiação adotiva como substitutiva, conferindo-lhe caráter irrevogável, e passou a anular os vínculos com a família biológica. Segundo Vargas (1998), isso abriu possibilidades para a legitimação da adoção de crianças com idade superior a sete anos, que já convivessem com os pais adotivos antes dessa idade.

Com o Código de Menores, de 1979, foram criadas a adoção plena e a adoção simples. A plena se referia à adoção de crianças com até sete anos de idade. Em caráter 
irrevogável, conferia ao adotado filiação substitutiva e os mesmos direitos dos filhos biológicos no que diz respeito à herança. A simples, referia-se à adoção de menores de 18 anos, que se encontravam em situação "irregular", tendo caráter revogável e filiação aditiva, não conferindo aos filhos adotivos os mesmos direitos quanto à herança (FONSECA, 1995; VARGAS, 1998).

No Código Civil de 2002 não se cogitam mais as adoções simples e plena, pois todas as adoções que se referem à criança e ao adolescente, ou seja, aos que ainda não completaram dezoito anos, regem-se pelas normas do ECA. É possível constituí-las apenas em processo judicial (e não mais por escritura pública, como antes previa o Código Civil de 1916).

Segundo ainda Fonseca, a evolução da legislação da adoção advém de três princípios "modernos": o interesse no bem-estar da criança; A igualdade entre os filhos biológicos e adotivos e a liberdade individual. "A criança passa a integrar a linhagem consangüinea da família adotiva, sendo criado de fato um vínculo de parentesco por meio da adoção" (FONSECA, 1995:123).

Em 1990, com a promulgação do ECA, aconteceram importantes mudanças na adoção brasileira, do ponto de vista legal, o que representou um avanço no reconhecimento da criança e do adolescente como sujeitos de direitos (ECA, 1990).

Atualmente, de acordo com o Artigo 43 do ECA, "a adoção poderá ser deferida ao adotante quando representar reais vantagens para o adotando e fundar-se em motivos legítimos" (BRASIL, 1991). Compreende-se, portanto, que a adoção passa a ser vista como um mecanismo que deve priorizar a criança, garantindo-lhe vantagens tanto do ponto de vista psicológico quanto jurídico. Assim, por meio da adoção procura-se propiciar um ambiente familiar favorável à formação da identidade da criança abandonada ou daquela cujos pais biológicos são considerados impossibilitados de exercer suas funções paternas. E, dessa forma, o fundamental passa a ser a proteção da criança, com vista ao interesse na garantia de seu bem-estar biopsicossocial, por meio de sua inserção em um ambiente familiar que lhe possa fornecer condições para um desenvolvimento saudável (FREIRE, 1991).

Segundo o ECA, em seus artigos 41 e 48, à criança adotada são conferidos os mesmos direitos e deveres, inclusive sucessórios, que cabem aos filhos biológicos. Uma 
vez adotada, a criança é desligada "de qualquer vínculo de pais e parentes, salvo os impedimentos matrimonias" (BRASIL, 1991). Ou seja, uma vez concretizado, o processo de adoção é irrevogável, já que se rompe qualquer vínculo jurídico de parentesco com a família biológica, podendo-se substituir inclusive o sobrenome pelo da família adotiva.

Sob o ângulo ético e jurídico, aqueles que desejam adotar uma criança devem apresentar-se à Vara da Infância e da Juventude para se inscreverem como candidatos à adoção, participar do estudo psicossocial e, se deferido o processo pelo Juiz, aguardar até que uma criança que seja compatível com o perfil desejado encontre-se disponível (SANTOS e PEREIRA, 1998).

A efetivação da adoção é precedida por um período denominado guarda, estabelecido por lei, com a finalidade principal de proporcionar experiência de convivência entre adotantes e adotando. De acordo com o ECA, os adotantes precisam ter no mínimo 21 anos, sendo pelo menos 16 anos mais velho do que o adotando. E, segundo o art. 42 do referido Estatuto, os ascendentes (avós) e os irmãos do adotando são impedidos de adotá-lo.

Diniz (1991) assinala que, embora a adoção de uma criança pareça um mecanismo relativamente simples, os adotantes esbarram na realidade do reduzido número de bebês que são entregues para adoção. Muitos acabam sendo desviados para as chamadas "adoções à brasileira", que ocorrem sem a mediação da justiça. Além disso, segundo o autor, poucas mães renunciam à criança logo após o nascimento. A grande maioria pratica o chamado “abandono moral e tardio" (FREIRE, 1991), praticado pelos pais que são incapazes ou impossibilitados de exercerem suas funções paternas, quando a criança já se encontra em idade mais avançada.

Por esses relatos, observa-se que o Estatuto da Criança e do Adolescente tem a perspectiva de evitar a perda dos filhos por pobreza. As crianças e a família passam a ter direitos, como ao da convivência familiar e comunitária.

Percebe-se, assim, que a adoção sempre existiu e, muitas vezes, era necessária para crianças e adolescentes cujas famílias biológicas não tinham condições de mantê-las. Mas, as limitações do Poder Público, quanto a garantir maior repasse de verbas para a Assistência Social, com vista ao fortalecimento de programas sociais que garantam melhores condições de saúde, educação, moradia, profissionalização e trabalho às famílias pobres, criaram uma dívida com a infância e a juventude brasileiras. 


\section{Capítulo II}

\section{APRESENTANDO A VARA DA INFÂNCIA E DA JUVENTUDE DO DISTRITO FEDERAL}

\subsection{A Vara da Infância e da Juventude (VIJ)}

A VIJ é subordinada ao Tribunal de Justiça do Distrito Federal e Territórios. Tem como objetivo garantir os direitos da criança e do adolescente no âmbito do Distrito Federal, por meio da prestação jurisdicional, assegurando-lhes condições para seu pleno desenvolvimento individual e social.

A Vara da Infância e Juventude, com jurisdição em todo o Distrito Federal, tem como instrumento norteador de seu trabalho o Estatuto da Criança e do Adolescente - Lei 8069, de 13 de julho de 1990 - que dispõe sobre a proteção integral da criança e adolescente.

Essa lei, que quebrou paradigmas vigentes, e instituiu outros, passou a entender a criança e o adolescente como pessoas que exigem prioridade absoluta e, para isso, enfatiza a importância da participação das instituições e da sociedade em geral na sua execução plena.

Por meio de suas equipes administrativa, jurídica e técnica, a VIJ/DF promove a resolução de conflitos e a regularização de situações que envolvem interesses infantojuvenis, buscando parcerias com entidades diversas, a fim de possibilitar o atendimento mais completo e humano dos que dependem de seus serviços.

Seu grande desafio é garantir para todos e sem distinção o atendimento previsto no ECA, permitindo que cidadãos sejam formados e que o papel da justiça se exerça frente a essas questões. Trata-se da garantia do que deveria ser natural, isto é, o direito de uma criança ser criança, no sentido mais amplo da palavra. Sua missão, portanto, envolve a garantia dos direitos daqueles em quem se depositam expectativas, possibilitando aos mesmos um futuro social melhor e mais justo.

A Vara da Infância e da Juventude do Distrito Federal fica situada na SGAN 909 Blocos C/D - Asa Norte - Brasília. 
Atualmente, são membros da VIJ: Juiz Titular da Infância e Juventude, Dr. Renato Rodovalho Scussel; Juiz Substituto, Dr. Fábio Martins de Lima; Juíza substituta, Dra. Priscila Faria da Silva; Diretora de Secretaria, Dra. Cristina Ferreira Vitalino; Diretora de Serviço de Apoio Administrativo, Dra. Simone Costa Resende da Silva; Coordenadora de Projetos Institucionais, Dra. Thais Botelho.

\subsection{A Seção de Adoção}

A Seção de Adoção é subordinada à Coordenadoria da Equipe Interprofissional, alterada pela Portaria n. ${ }^{\circ} 17 / 2004$, e é chefiada pelo Sr. Walter Gomes de Sousa, cuja substituta é a Sra. Eliane Cristina Martins de Resende Andrade.

À Seção de Adoção compete planejar e executar ações de caráter psicossocial e educativo, no que se refere a todos os procedimentos relativos à adoção no Distrito Federal, de acordo com o disposto nos Artigos 39 a 52 do ECA. Essa Seção tem como função assessorar tecnicamente o Juiz competente no seu mister de garantir à criança e ao adolescente o direito fundamental à convivência familiar, na condição de filhos. Para tanto, tem como filosofia atuar técnica e eticamente com o fim de mediar a relação entre necessidade/interesses de crianças e adolescentes, passíveis de adoção, e pessoas interessadas em adotar, ao esgotarem-se as possibilidades de permanência dessas crianças e adolescentes na família biológica.

Suas principais atividades são: orientar e prestar esclarecimentos sobre adoção; atender pais, mães e gestantes que desejam entregar o filho para adoção; cadastrar e apresentar crianças e adolescentes para adoção; acompanhar o estágio de convivência entre as famílias e as crianças/adolescentes cadastradas; realizar estudo psicossocial em processos de inscrição com famílias que desejam adotar e em processos de adoção, o que possibilita um momento de reflexão, para o adotante, sobre seu projeto de adotar.

Assistentes sociais, psicólogos e pedagogos participam também dos plantões diários, que funcionam na Seção, de segunda a sexta-feira, no horário de $13 \mathrm{~h}$ às 19h, para atendimento e orientação dos genitores (pais) que entregam seus filhos para adoção, ou de pessoas interessadas em adotar. $\mathrm{O}$ atendimento no plantão é distribuído mediante uma 
escala mensal elaborada pela secretária da Seção de Adoção, que resulta em aproximadamente de dois a seis plantões por mês.

O trabalho realizado na Seção de Adoção com as famílias interessadas em adotar, consiste em orientação por meio de palestras. Estas têm como objetivo a prevenção, para que essas famílias possam acolher crianças e adolescentes de forma responsável, sendo, para tanto, auxiliadas desde o início do processo, pois se acredita que, dessa forma, a decisão possa ser mais consciente e amadurecida.

\subsection{O processo de adoção}

O processo de adoção é iniciado pela inscrição para esse fim, como uma exigência legal prevista no artigo 50 do ECA. A inscrição é um expediente por meio do qual o interessado se compromete, perante a justiça, a acolher de maneira responsável crianças ou adolescentes passíveis de adoção, isto é, em relação as quais se esgotaram todas as possibilidades de reintegrá-las à família biológica.

A inscrição acontece quando o(a) interessado(a) comparece à palestra, trazendo seus documentos e fotografia, dele(a) e da família. Após a palestra, é designado um profissional (assistente social, psicólogo ou pedagogo) da Seção de Adoção para acompanhar o processo de inscrição. Esse profissional entra em contato com o(a) interessado(a) e sua família, para agendar entrevistas na Vara da Infância e da Juventude, fazendo, depois, uma visita à residência, sem aviso prévio, com a finalidade de conhecer melhor a família adotante.

O parecer que o profissional encaminhará ao Juiz da Vara da Infância está baseado no que ele pôde perceber do(a) requerente e de sua família, durante as entrevistas e a visita domiciliar. Nessa tarefa, o profissional tem uma enorme responsabilidade, uma vez que é por meio do seu relatório que o Juiz pode-se considerar habilitado ou não, a proporcionar um lar a uma criança privada da convivência familiar.

Dessa forma, o estudo psicossocial possibilita um momento de reflexão, no qual o(a) requerente pode pensar melhor sobre o seu projeto de adotar. Esse estudo é orientado(a) para que o(a) requerente compreenda suas motivações para adoção, auxiliando-o(a) na decisão de adotar, prevenindo eventuais distorções e preconceitos que 
possam vir a dificultar essa decisão e esclarecendo dúvidas com relação ao processo legal, dentre outras. É também uma oportunidade para o requerente ser assistido, individualmente, por um profissional com conhecimento e experiência no processo.

Em geral, o estudo psicossocial começa no mês subseqüente ao da palestra e dura em média trinta dias para ser concluído pelo profissional da Seção de Adoção, podendo variar em função da necessidade de se obter mais informações ou providenciar encaminhamentos para o caso.

Feito o estudo, o profissional elabora um relatório, dando seu parecer, e o encaminha para apreciação do Juiz. Antes de se manifestar, no entanto, o Juiz consulta os promotores de Justiça do Ministério Público, que irão analisar o processo e verificar se estão cumpridos todos os requisitos legais exigidos pelo ECA. Depois disso, o processo retorna ao Juiz para que ele dê um veredicto final.

Portanto, o tempo de tramitação de um processo de inscrição para adoção na Vara da Infância e da Juventude do DF, depende da manifestação dessas três partes (Seção de Adoção, Promotoria de Justiça e Juiz), o que leva aproximadamente três meses.

Uma vez aprovada a inscrição pelo Juiz, o(a) requerente estará habilitado(a) a acolher uma criança ou adolescente a qualquer momento. Entretanto, em alguns casos, se for observada alguma situação de risco para o adotando, ou algo que comprometa seu bom desenvolvimento, a inscrição não será autorizada.

O tempo de espera do requerente é variável, pode demorar poucos meses ou até dois anos, sendo que esse tempo pode se tornar ainda maior em função do grau de exigência do interessado em relação ao perfil da criança ou adolescente desejados. É importante que o(a) requerente aproveite esse momento de espera para se preparar, fazendo leituras, trocando idéias com outras pessoas, conhecendo melhor o universo da adoção. A VIJ/DF faz uma parceria com o Projeto Aconchego, um grupo de apoio à adoção formado por pais adotivos e simpatizantes da causa, que realizam reuniões no segundo sábado de cada mês, na Biblioteca do Cruzeiro. Este Projeto tem como objetivo orientar e apoiar ações que promovam a convivência familiar e comunitária de crianças e adolescentes em situação de abrigamento no Distrito Federal.

O requerente poderá solicitar cópia do seu processo de inscrição para enviá-lo a outras cidades (Comarcas) tão logo ele seja aprovado pelo Juiz. Outra alternativa é procurar 
diretamente a Vara da outra Comarca e lá solicitar a inscrição aprovada pela Vara do DF. O Juiz daquela Comarca irá solicitar o estudo psicossocial ao Juiz da VIJ/DF, via "Carta Precatória".

O requerente será comunicado, por telefone, quando chegar a sua vez de conhecer uma criança ou adolescente cadastrados para adoção. Será convidado(a) a comparecer à Seção de Adoção, onde conhecerá a criança ou o adolescente primeiramente por meio de fotografia. Se aceitar o perfil conhecido, será encaminhado(a) à instituição onde a criança ou adolescente se encontram, para que possa conhecê-los pessoalmente. No caso de recémnascida, se, após conhecê-lo, desejar acolhê-lo, poderá levá-la imediatamente para casa.

No caso de criança com idade superior a um ano, a lei prevê um período de adaptação, chamado "Estágio de Convivência", durante o qual o(a) requerente e a criança terão encontros regulares, acompanhados por um profisssional da Seção de Adoção, até que as condições para retirada da criança do abrigo sejam satisfatórias para ambos.

O requerente receberá todas as informações que estiverem disponíveis na Seção de Adoção. Em geral, a Seção possui informações que são transmitidas pela maternidade ou abrigo onde a criança se encontra e documentos que compõem o processo/dossiê da criança, denominado "Pasta Especial".

Se uma mãe manifestar interesse em entregar seu bebê ou criança para um(a) requerente, este(a) deverá vir à Vara da Infância e da Juventude com a criança e a mãe biológica para que o profissional de plantão da Seção de Adoção possa atendê-los. Esse profissional irá conversar com a mãe biológica a fim de melhor conhecer os seus motivos em optar pela entrega do/a filho, o grau de vinculação afetiva entre ela e a criança, bem como verificar as possibilidades dessa criança permanecer na família de origem. Após o atendimento, o profissional fará um relatório informativo do caso e o encaminhará para apreciação do Juiz, no mesmo dia do atendimento. De posse do relatório técnico, o juiz imediatamente ouvirá a mãe biológica em audiência e decidirá sobre o caso, atendendo o que for melhor para a criança.

Acolher uma criança sem o intermédio da Vara da Infância e da Juventude pode ser muito arriscado, além do que, registrá-la em cartório, omitindo suas origens (a chamada adoção "à brasileira"), constitui crime passível de punição. 
Os riscos de acolher uma criança diretamente de sua genitora ou de pessoas conhecidas, envolvem desde a possibilidade de perda da criança, até infortúnios futuros por parte de parentes biológicos, que poderão querer manter alguma espécie de vínculo com $o(a)$ requerente ou a criança.

Atualmente existem vinte e uma instituições que abrigam crianças e adolescentes no Distrito Federal. As crianças cadastradas para adoção estão espalhadas por diversos abrigos. Entretanto, nem todos os abrigados estão disponíveis para adoção. Na verdade, o número de crianças prontas para serem adotadas é muito inferior ao número total das que estão sob abrigo.

Quando uma criança com idade superior a dois anos é cadastrada para ser adotada, imediatamente uma família é procurada para recebê-la, mediante consulta à lista de espera de pessoas inscritas para aquele perfil. Nenhuma criança cadastrada para adoção fica esperando para ser acolhida, a menos que, no momento, não exista alguém que possa acolhê-la.

A adoção se formaliza efetivamente quando o(a) requerente recebe o mandado do Juiz autorizando a anulação do registro de nascimento antigo e a lavratura da nova certidão, na qual constará o nome do(a) requerente como pai/mãe da criança, sem qualquer referência aos genitores ou ao fato de ela ter sido adotada.

Até que a adoção seja efetivada, ou seja, enquanto o processo estiver em tramitação, os "pais biológicos" que não perderam o direito legal sobre a criança, podem contestar a adoção pleiteada. Caso isso aconteça, é designado um profissional que entrevistará o(a) requerente, os genitores e a criança, a fim de informar ao juiz a situação das duas famílias. Com isso, o juiz terá elementos para decidir com quem ficará a criança, visando maiores benefícios para a mesma.

Depois de efetivada adoção, os pais biológicos não podem recuperar a criança. Mas mudar o seu nome próprio é uma questão delicada. O ideal é que seja mantido o nome original se a criança já atende por ele. Afinal, o nome tem a ver com a identidade da pessoa e não há nada que sintetize melhor essa identidade do que ele. Aceitar o nome da criança significa aceitá-la integralmente, sem restrições. O adotado tem uma história anterior ao momento em que foi encontrado pelo(a) requerente e "trocar" o seu nome não significa apagar esta história. Além disso, a tentativa de negação do passado do adotado pode ser 
danosa para a construção de sua identidade. Todavia, quando o nome da criança lhe traz constrangimentos, por ser muito exótico, sugere-se aos pais que escolham outro nome de sonoridade parecida. Já o sobrenome da criança é alterado após a adoção, passando a constar o sobrenome dos adotantes.

É possível aos adotados terem acesso ao processo de sua adoção anos mais tarde, caso assim o desejem, porque o mesmo fica arquivado na VIJ/DF.

Ainda em relação ao processo de adoção, vale ressaltar que o fato de o requerente não poder acolher a criança quando é chamado a conhecê-la, não altera sua posição na fila. As pessoas que se inscrevem para adotar criança na VIJ-DF são convidadas a participar de encontros em grupo, cujo objetivo é transformar o tempo de espera em tempo de preparação. Esse processo é denominado "pré-natal da adoção" e, nele, várias questões importantes são abordadas. No pré-natal o(a) requerente também tem a oportunidade de conhecer outras pessoas que compartilham do seu objetivo, além de poder tirar dúvidas com as que já realizaram adoção pela Vara da Infância e Juventude. Devido ao pequeno número de funcionários hoje na Seção de Adoção o "pré-natal da adoção" foi suspenso. A preparação passou a ser desenvolvida por meio de convênios e parcerias com a ONG Projeto Aconchego, a Universidade Católica de Brasília (UCB) e com a Universidade Paulista (UNIP), que criaram o projeto Pré-Adoção para desenvolver a preparação e o apoio necessário às pessoas que estão inscritas para adoção na VIJ/DF.

A VIJ/DF acompanha a família que adota até o término do processo, ou seja, enquanto o pedido de adoção estiver sendo analisado pelo profissional da Seção de Adoção. Caso haja necessidade de algum tratamento ou acompanhamento paralelo ou posterior à adoção, o caso poderá ser encaminhado a um profissional indicado ou à rede pública.

É comum surgirem muitas dúvidas durante o processo de adoção. Devido a isso, faz parte da tarefa da Seção de Adoção orientar e acolher o(a) requerente no que for preciso. Este(a) deve sentir-se à vontade para procurar o profissional responsável pelo seu caso sempre que necessário. É importante que ele(a) esteja bem seguro sobre o que procura. 


\subsection{O Serviço Social na Seção de Adoção}

O Serviço Social na Seção de Adoção da VIJ/DF executa sua atividade profissional em equipe multiprofissional, formada por assistentes sociais, psicólogos e pedagogos. Essa equipe tem a competência de fornecer subsídios por escrito mediante laudos, relatórios e pareceres técnicos, elaborados a partir de entrevistas e observações efetuadas na própria Seção e nas visitas domiciliares.

A equipe multidisciplinar desenvolve trabalho de encaminhamento, com base em entrevistas realizadas, seja no plantão, seja durante estudos psicossociais.

A Seção realiza outros encaminhamentos, quando necessário, ao Centro de Orientação Médico Psicopedagógica (COMPP), em caso de transtornos mentais; ao Hospital Universitário de Brasília (HUB), em caso de avaliação nutricional e outros; a Universidade Católica de Brasília (UCB), em caso de terapia psicológica; ao Centro Universitário de Brasília (UNICEUB), para programas de nutrição, etc. Orienta também nos casos em que os usuários apresentam-se ansiosos, preocupados, solicitando informações sobre o processo de adoção. Ademais, realiza trabalho preventivo, informando as pessoas para que procurem acolher crianças e adolescentes de forma madura e responsável. O profissional de Serviço Social executa também a função de substituta na chefia da Seção.

\subsection{Meios e instrumentais de trabalho}

Os profissionais da Seção de adoção utilizam um conjunto de instrumentais técnicooperativos no processo de intervenção, não havendo diferença de instrumentais dos assistentes sociais, dos psicólogos e dos pedagogos, apesar de cada um ter a sua forma própria de intervir. As entrevistas são utilizadas como fontes de obtenção de dados, guiada, cada uma, por um roteiro apropriado. Cita-se, por exemplo, o roteiro para atendimento no plantão, que é composto de data, nome do profissional responsável pelo atendimento, nome dos envolvidos, endereço, telefones, descrição dos fatos, orientação e encaminhamentos, observações e conclusões finais e, quando necessário, espaço para um pequeno relato. 
Outro instrumento é o relatório de inscrição, o qual fornece ao Juiz as informações sobre o(a) requerente, o motivo da procura, a composição familiar, características da criança esperada, a situação habitacional, a situação econômica e financeira e ainda um parecer após analise do contexto.

Há ainda o relatório técnico de adoção, instrumento pelo qual é apresentada ao Juiz a qualificação do adotante, do adotando, dos genitores e a descrição de sua história, também com um parecer realizado após estudo psicossocial.

As estatísticas de adoção e inscrição também fazem parte do instrumental e são utilizadas para o conhecimento da situação da adoção no DF. Há uma outra modalidade de estatística, denominada "estatística de adoção por extensão", que informa os dados do requerente, do adotando e o parecer da Seção de adoção em relação ao pedido efetuado. A adoção por extensão acontece com casais em que o(a) parceiro(a) adota o(a) filho(a) biológico ou adotado - do(a) companheiro(a).

É utilizado ainda um instrumental configurado no uso da brinquedoteca ou berçário, quando existe a necessidade de entrevistar os pais ou responsáveis sem que as crianças participem. Há ainda um instrumental de encaminhamento e o atestado de comparecimento.

\subsection{Demanda da Seção de Adoção}

A Seção de Adoção tanto atende demanda específica de pessoas interessadas em ter filhos por meio da adoção de crianças e adolescentes, de pessoas que já acolheram crianças ou adolescentes e querem regularizar a situação, de genitores que querem entregar seus filhos para adoção e, nos plantões, de pessoas que precisam de orientação para adotar. 


\section{Capítulo III}

\section{APRESENTAÇÃO DAS INSTITUIÇÕES DE ABRIGAMENTO}

Neste capítulo estão sistematizadas as informações obtidas mediante entrevistas realizadas com as assistentes sociais das seguintes instituições de abrigo: Casa de Ismael, Nosso Lar, Aldeias Infantis SOS e Larzinho Chico Xavier e com a psicóloga da instituição Casa do Caminho, cujo conteúdo interessam particularmente à pesquisa e aos seus objetivos.

\subsection{Casa de Ismael - Lar da Criança.}

A Casa de Ismael foi fundada em 1968 e situa-se na SGAN - Av. W5 QD. 913 Conj. G - Asa Norte - Brasília - DF. Trata-se de uma instituição filantrópica, sem fins lucrativos, que funciona associada à Congregação Espírita de Brasília - DF. Segundo a assistente social entrevistada o abrigo é mantido por meio da ajuda da comunidade espírita de Brasília e convênios firmados com o governo do Distrito Federal. É administrada por um presidente e um corpo de diretores que coordenam e/ou supervisionam as diversas atividades desenvolvidas para a manutenção da instituição. Além destes, que atuam voluntariamente, outros contribuem para o seu funcionamento, cumprindo as seguintes funções:

Quanto ao abrigamento, a instituição acolhe, em regime de abrigo, crianças e adolescentes com idades de 2 a 18 anos, encaminhadas pelo Conselho Tutelar e pela Vara da Infância e da Juventude do DF, por encontrarem-se em situação de risco social. Exemplo: quando pessoas observam maus tratos na família e recorrem ao SOS Criança para denunciar. Segundo a profissional entrevistada a instituição acolhe 60 crianças. Destas, 12 são filhos de pais sociais (filhos do casal de cuidadores sociais, funcionários da instituição, que residem e cuidam das crianças e adolescentes institucionalizados) e 35 estão na faixa etária de 2 a 11 anos. Os adolescentes são em número de 25 e situam-se na faixa de 13 a 18 anos de idade. Destes, dezesseis adolescentes e quinze crianças estão cadastradas para adoção na VIJ/DF, sendo que oito crianças e apenas dois adolescentes encontram-se em 
estágio de convivência. (período de adaptação, previsto no ECA, durante o qual a família habilitada pela VIJ/DF e a criança tem encontros regulares, acompanhados por um profissional da Seção de Adoção, até que as condições para retirada da criança do abrigo sejam satisfatórias para ambos).

Em relação ao apoio e orientação sócio-familiar, a profissional entrevistada relatou que consiste em assistir e orientar as famílias de crianças e adolescentes abrigados, com o objetivo de promover a reintegração familiar e identificar casos de adoção. No momento da realização desta pesquisa, a função era desempenhada pela profissional do Serviço Social e por voluntários e estagiários do abrigo.

O apoio sócio-educativo do abrigo atende, em regime de creche, crianças de zero a seis anos de idade, que ali vivem ou provenham da comunidade local. A instituição funciona segundo o modelo de casas lares. Dispõem de nove casas, oito que abrigam uma mãe social ou um casal de pais sociais e até 8 crianças e adolescentes, podendo, os cuidadores, ter no máximo 2 filhos biológicos. Dispõem ainda da denominada casa da juventude, que abriga somente meninos adolescentes.

Para o atendimento das necessidades de crianças e adolescentes abrigados a instituição conta com diversos serviços, dentre os quais se destacam: Educação, pois, além do atendimento em creche até o jardim III, para crianças de 0 a 6 anos de idade, todas as crianças e adolescentes, a partir de 7 anos, freqüentam escolas da rede pública. Oferece reforço escolar com o Projeto Segundo Tempo, e o Programa de profissionalização, o Adolescente Aprendiz. E possui oficinas pedagógicas que funcionam com o apoio de uma professora contratada e de profissionais voluntários.

$\mathrm{O}$ atendimento à saúde e a alimentação é realizado por uma nutricionista que é responsável pela alimentação oferecida no refeitório local. Relacionados a esse atendimento, existem ainda, no abrigo: um consultório odontológico, no qual todas as crianças e adolescentes são atendidos uma vez por semestre, salvo urgências, por dentistas voluntários; um consultório de psicologia, no qual uma profissional voluntária realiza trabalho de orientação às mães sociais. A psicóloga é responsável também pelo encaminhamento de crianças e adolescentes a atendimento psicológico, geralmente realizado em clínicas particulares, gratuitamente, ou mediante pagamento. 
Os recursos humanos contratados pela instituição são constituídos do seguinte pessoal: 1 (uma) cozinheira, 4 (quatro) adolescentes aprendizes, 1 (um) auxiliar de monitoria, 6 (seis) auxiliares de serviços gerais, 1 (uma) coordenadora pedagógica, 5 (cinco) monitoras, 1 (uma) nutricionista, 1 (uma) lavadeira, 2 (duas) assistentes sociais, 1 (um) motorista, 1 (uma) zeladora, 1 (uma) coordenadora financeira, 1 (uma) coordenadora pedagógica e 1 (um) instrutor de educação física.

A assistente social revelou que a instituição conta ainda com um grupo de estudantes estagiários de Serviço Social, Psicologia, e Educação. Há também um grupo de voluntários composto por médicos, terapeutas, dentistas, nutricionistas, psicóloga, professores, integralizando um total geral de 70 voluntários.

Segundo a assistente social o Serviço Social na instituição tem como objetivo trabalhar com a família dos abrigados, por meio de reuniões, visando orientar sobre problemas de alcoolismo e drogadição e realizar encaminhamentos de acordo com a demanda das crianças e adolescentes. Mas, devido a grande demanda das famílias e das crianças e adolescentes, este trabalho está sendo realizado por estagiários da psicologia e da educação. Além disso, o Serviço Social distribui calçados e roupas, conforme solicitação, e auxilia na melhoria da habitação, intermediando a doação de material de construção para as famílias que pretendem resgatar seus filhos da instituição.

A assistente social consultou a contabilidade e informou que o custo total dos gastos da instituição correspondeu em 2006 a R $\$ 811.302,74$, que foram arcados com $61 \%$ da participação do poder público, e com $39 \%$ da sociedade civil, sob a forma de doações dos associados espíritas que freqüentam a instituição. Ao todo, foram atendidas, em 2006, 57 crianças e adolescentes da meta de 60 conveniadas, o que significou uma per capita de R\$1.186,00/abrigados por mês.

De acordo com a assistente social os maiores problemas enfrentados por ela na instituição são em relação aos conflitos entre as mães socias e as crianças ou adolescentes abrigados e a necessidade de iluminação na quadra de esportes, pois os institucionalizados contam com poucas alternativas de lazer, principalmente nos finais de semana. 


\subsection{Nosso Lar}

O abrigo Nosso Lar foi fundado em 1974 e localiza-se na SAIS - Conj. C, Lote 29, Núcleo Bandeirante - Distrito Federal. Trata-se de uma instituição filantrópica, sem fins lucrativos. Segundo a assistente social entrevistada, o abrigo é mantido por meio da ajuda da comunidade espírita de Brasília e por convênios firmados com o Governo do Distrito federal, e é administrada por um presidente e um corpo de diretores voluntários que coordenam e/ou supervisionam as diversas atividades desenvolvidas para a sua manutenção. A instituição cumpre as seguintes funções:

Quanto ao abrigamento, acolhe, em regime de abrigo, crianças e adolescentes com idade de 0 a 17 anos, encaminhados pelo Conselho Tutelar e pela Vara da Infância e da Juventude do DF, ou entregues pelos responsáveis que estão sem condições socioeconômicas. Neste caso a instituição informa imediatamente a VIJ/DF a ocorrência. Segundo a profissional, o abrigo atende 59 crianças, de 0 a 12 anos de idade, e 11 adolescentes, de 13 a 17 anos de idade. Desse conjunto, treze crianças e oito adolescentes estão cadastrados para adoção na VIJ/DF, sendo que três crianças e apenas um adolescente encontram-se em estágio de convivência com famílias habilitadas pela VIJ/DF.

Em relação ao apoio e orientação sócio-familiar, a assistente social declarou que a instituição procura identificar casos de adoção e informar a VIJ/DF. Também trabalha com a família dos abrigados que mantêm vínculos por meio de visitas a instituição, visando à reintegração das crianças ou dos adolescentes, orientando e fazendo encaminhamentos.

As famílias são orientadas a procurar o Centro de Referência da Assistência Social (CRAS), que desenvolve ações e serviços básicos continuados para famílias em situação de vulnerabilidade social, da Região Administrativa em que residem, para serem inseridas em programas sociais, visando a sua reestruturação. Contudo, como salientou a profissional, raramente essas famílias conseguem se reestruturar e reintegrar seus filhos.

Quando a família consegue trabalho, a instituição, durante seis meses (período considerado suficiente pelo abrigo, para a família conseguir se reestruturar) doa cesta básica para ela. E as crianças ou adolescentes são transferidos, por ocasião da reintegração, para uma escola próxima a residência dessa família. 
Segundo assistente social, quando à família do abrigado não possui imóvel, a instituição procura recursos do Governo do Distrito Federal para incluí-los em programas de habitação, ou reforma do imóvel para aqueles que possuem lote com um barraco, mas não tem condições de melhorá-lo. No momento da realização da pesquisa, apenas duas famílias foram beneficiadas com a reforma do barraco em que residiam, sendo um na comunidade da Estrutural e outra em Planaltina.

Esta instituição também funciona segundo o modelo casas lares e dispõe de seis casas, que abrigam uma mãe social e uma cuidadora, que a substitui na sua folga, e até 14 crianças e adolescentes. Portanto, as casas possuem capacidade de atender até 84 crianças e adolescentes. No momento da realização da pesquisa, a instituição atendia 84 crianças e adolescentes de ambos os sexos, que estavam sob os cuidados de 7 mães sociais.

Todas as crianças e adolescentes, a partir de 7 anos, freqüentam escolas da rede pública. A instituição oferece reforço escolar e educação artística, que engloba o programa de profissionalização o Adolescente Aprendiz; e possui oficinas pedagógicas que funcionam com o apoio de profissionais voluntários.

Quanto ao atendimento à saúde e à alimentação, uma nutricionista é responsável pela alimentação oferecida no refeitório local, tendo o abrigo ainda um consultório odontológico. $\mathrm{O}$ atendimento médico é realizado nos hospitais da rede pública de saúde, sendo o Hospital Materno Infantil de Brasília (HMIB) o mais utilizado.

Segundo a profissional entrevistada, os recursos humanos contratados pela instituição são constituídos do seguinte pessoal: 2 (duas) cozinheiras, 1 (uma) secretária, 2 (duas) lavadeiras, 2 (dois) funcionários serviços gerais, 1 (uma) assistente social. As crianças são atendidas por dentistas voluntários e por uma psicológa, também voluntária, que realiza trabalho de orientação às mães sociais, principalmente quando a criança ou o/a adolescente, que está sob seus cuidados há muito tempo, sai da instituição para reintegração ou adoção.

Dentre os voluntários da instituição, há um grupo composto por médicos, terapeutas, dentistas, nutricionistas, psicóloga, professores, estimuladores e recreadores. Desse conjunto não fazem parte estagiários, pois segundo a assistente social não há profissional disponível para supervisioná-lo. 
A profissional revelou, ainda, que o abrigo não oferece programas extracurriculares às crianças e aos adolescentes. Estes realizam essas atividades fora da instituição. Quando os institucionalizados querem fazer determinado curso, a instituição procura informação e solicita bolsa de estudo. As atividades esportivas como natação, são realizadas no SESC da Asa Sul, que concede algumas vagas para os institucionalizados.

Como parte da sua estrutura, o Nosso Lar conta com sala de aula, biblioteca, brinquedoteca, consultório dentário, consultório médico e psicológico, cozinha industrial, salão de eventos, quadra poliesportiva, parque infantil e lavanderia semi-industrial.

Consultando a contabilidade a assistente social relatou que a instituição arrecada R\$11.000,00 mensais da Comunhão Espírita de Brasília, R\$5.000,00 da SEDEST (Secretaria de Estado de Desenvolvimento Social e Trabalho) e contribuições variáveis, sob a forma de doações.

Segundo a mesma entrevistada, o maior problema enfrentado na instituição é quanto à localização das famílias das crianças ou adolescentes abrigados, para orientá-las sobre a importância das visitas, pois essas famílias acabam se escondendo e abandonando seus filhos, com medo de ter que resgatá-los sem condições socioeconômicas para isso.

\subsection{Aldeias Infantis SOS Brasília}

A instituição denominada Aldeias Infantis SOS foi fundada em 1968 e localiza-se na SGAN W-5 Norte-Q 914 conj. F - Asa Norte Brasília DF. Trata-se de um abrigo de caráter filantrópico, sem fins lucrativos, que é dirigido por um profissional componente de seu quadro de pessoal. Funciona associada à Kinderdof, uma associação civil de direito privado com sede na Áustria, que tem por finalidade atender crianças e adolescentes que se encontram em situação de vulnerabilidade social.

Segundo a assistente social entrevistada a instituição cumpre as seguintes funções: acolhe em regime de abrigo crianças e adolescentes com idade de 4 meses a 18 anos, de ambos os sexos, que são encaminhadaos pelo Conselho Tutelar e pela Vara da Infância e da Juventude do DF por se encontrarem em situação de risco social. Atende 89 crianças e adolescentes. Destes, 12 crianças e 9 adolescentes estão cadastradas para adoção na 
VIJ/DF, sendo que, três crianças se encontram em estágio de convivência com famílias habilitadas pela VIJ/DF.

Quanto ao apoio e a orientação sócio-familiar, a instituição orienta algumas famílias de crianças e adolescentes abrigados, com o objetivo de promover a reintegração familiar dos mesmos e de identificar casos de adoção. A partir da reintegração das crianças ou adolescentes, as famílias recebem orientações e encaminhamentos. Por meio destes expedientes, tais famílias são informadas a procurar os CRAS (Centro de Referência de Assistência Social) da Região Administrativa em que residem para serem inseridos em programas sociais, com o propósito de reestruturá-las. Durante a fase de reestruturação, a instituição dôa cesta básica à família pelo tempo que a mesma necessitar. Procura promover visitas profissionais às famílias que reintegraram seus filhos por algum tempo, com o objetivo de perceber a vinculação e o desenvolvimento das crianças.

Segundo a assistente social entrevistada, a instituição de abrigo funciona segundo o modelo de casas lares. Dispõe de 12 casas, que abrigam, cada uma, uma mãe social e até oito crianças e adolescentes, possuindo, portanto, capacidade de atender um total de até 96, entre crianças e adolescentes. No momento da realização da pesquisa, a instituição atendia 89 crianças e adolescentes de ambos os sexos, que estavam sob os cuidados de 12 mães sociais.

Em relação a educação, Todas as crianças e adolescentes, a partir de 7 anos, freqüentam a escola, sendo que alguns possuem bolsa de estudo na rede privada de ensino e, a maioria, na rede pública. A instituição oferece reforço escolar para algumas crianças ou adolescentes que possuem "padrinhos" e custeiam o serviço e aulas de espanhol oferecidas por uma professora voluntária.

Quanto ao atendimento à saúde, este é realizado nos hospitais da rede pública e a alimentação é confeccionada, individualmente, pelas mães sociais.

Os recursos humanos contratados pela instituição são constituídos do seguinte pessoal: 12 (doze) mães sociais, 1 (uma) assistente social, 2 (duas) seguranças, 1 (um) assistente pedagógico, 1(um) facilitador de jovens, 1 (um) assistente administrativo, 1 (um) gestor, 1 (um) auxiliar de serviços gerais,1 (um) assistente de manutenção.

Quanto aos programas extracurriculares, a entrevistada declarou que o abrigo não os oferece, sendo as crianças e os adolescentes encaminhados para realizá-los fora da 
instituição. E quando os institucionalizados querem fazer determinado curso, ela procura informação e solicita bolsa de estudo, ou os padrinhos das crianças ou adolescentes os financiam.

A maior dificuldade encontrada pela instituição, é segundo a assistente social entrevistada, em relação à capacitação dos jovens para o futuro, porque quando os mesmos chegam à instituição já se encontram em uma faixa etária defasada da série escolar que deveriam cursar e, assim, não conseguem acompanhar o conteúdo das disciplinas próprias da sua idade.

\subsection{Casa do Caminho}

A instituição foi fundada em 1987, por Ciro Heleno Silvano e, segundo a psicóloga entrevistada, atende 66 crianças e adolescentes de ambos os sexos em regime de abrigo. Destas, 20 estão cadastradas para adoção. Trata-se de uma instituição filantrópica sem fins lucrativos que é dirigida por voluntários e mantida por meio de ajuda da comunidade e convênios firmados com o Governo do Distrito Federal. Localizada na QNJ 10, Área especial 06, Taguatinga Norte-DF a instituição possui $15.000 \mathrm{~m}^{2} \mathrm{com} 3.000 \mathrm{~m}^{2}$ de área construída, contendo 5 casas lares, refeitórios, cozinha e lavanderia industrial, além de almoxarifado e consultório psicológico e médico-odontológico.

Segunda a entrevistada, a instituição cumpre as seguintes funções: acolhe, em regime de abrigo, 66 crianças e adolescentes de ambos os sexos, com idade entre 3 a 18 anos, além de 25 crianças na creche, na faixa etária de 3 e 4 anos. As crianças e os adolescentes são encaminhados pelo Conselho Tutelar e pela Vara da Infância e da Juventude do DF, por se encontrarem em situação de risco social. Nesta instituição, 18 crianças e adolescentes estão cadastrados para adoção. Desses, 06 são crianças e, 12 , adolescentes. Apenas uma criança se encontra em estágio de convivência com família habilitada pela VIJ/DF.

Quanto ao apoio e orientação sócio-familiar, o acompanhamento da família é realizado pela psicóloga entrevistada. Tal orientação é feita por meio de entrevista, que visa recolher informações para orientação visando a reintegração familiar das crianças e dos adolescentes abrigados. Para as poucas crianças que conseguem ser reintegradas, a entidade 
mantém, mensalmente, fornecimento de cestas básicas e, por algum tempo, doação de outros benefícios, como uniforme escolar, vestuário e material escolar.

Esta instituição de abrigo também funciona segundo o modelo de casas lares. Dispõe de quatro casas, que abrigam, cada uma delas, um casal de pais sociais e até 14 crianças e adolescentes. Portanto, a instituição possui capacidade para atender até 56 abrigados, entre crianças e adolescentes. No momento da realização da pesquisa, a instituição atendia 50 crianças e adolescentes de ambos os sexos, que estavam sob os cuidados de quatro casais de pais sociais.

Segundo a entrevistada, as crianças e jovens freqüentam escolas públicas e as seguintes escolas particulares, por meio de bolsas de estudos: Encanto Infantil, Colégio Santa Terezinha, Dinâmico, Isaac Newton e JK.

O tratamento de saúde é geralmente realizado pelo Departamento Médico do SESI e pelo Posto de Saúde de Taguatinga - DF. As cirurgias são atendidas pelo Hospital das Forças Armadas (HFA), por meio de convênio, e pelo Hospital Regional de Taguatinga (HRT), enquanto o atendimento em fonoaudiologia é realizado por duas profissionais em seus próprios consultórios, dentro da instituição e pelo COMPP (Centro de Orientação Médico-Psico-Pedagógica), e psicológico, pela psicóloga do abrigo, no ambiente da instituição. Dois dentistas e um ortodontista atendem em seus consultórios voluntariamente.

$\mathrm{O}$ esporte e lazer oferecidos pela instituição constituem atividades que incluem passeios fora da instituição. Estes passeios consistem em visitas ao Zoológico, Cinema, Lanchonete, Circo, Teatro, Museus e Parques. O SESI fornece ambiente e professores para diversas atividades esportivas.

Quanto aos recursos humanos contratados pela instituição, existem os seguintes: 4 (quatro) casais de pais sociais, 1 (uma) cozinheira, 1 (uma) lavadeira, 1 (uma) auxiliar de serviços gerais, 1 (uma) gerente, 1 (um) motorista, 2 (duas) monitoras, 1 (uma) psicóloga.

A instituição conta ainda, segundo a psicóloga entrevistada, com um grupo de voluntários composto por quatro médicos, três dentistas e um psicólogo.

Quanto aos programas extracurriculares, o abrigo oferece oficina de mosaico, um computador em cada casa lar com acesso a internet, além de apresentações de peças teatrais instruindo sobre sexualidade e cidadania. Há também TV a cabo e vídeos cassetes em todas 
as casas-lares, estimulando crianças e jovens a assistirem programas próprios para sua idade. Conta, também, a instituição, com salas próprias para realizar tarefas escolares, bem como aulas de reforço acompanhadas por voluntários nas tarefas de casa e estudos preparatórios para prova.

No que diz respeito às dificuldades encontradas pela instituição, a psicóloga declarou que os voluntários que auxiliam no reforço escolar das crianças e dos adolescentes não são comprometidos, pois não apresentam assiduidade nas aulas de reforço escolar que devem ministrar.

\subsection{Larzinho Chico Xavier}

Este abrigo foi fundado em 1999 e situa-se nos fundos do terreno do Lar para Idosos Chico Xavier, no Núcleo dos Bandeirantes, onde funciona de forma independente, abrigando 50 entre crianças e adolescentes. Segundo a assistente social entrevistada, o Larzinho (como é chamado) é mantido por doações da comunidade espírita de Brasília e dirigida por voluntários.

A instituição cumpre as seguintes funções: acolhe em regime de abrigo crianças e adolescentes de ambos os sexos, com idade entre 2 a 17 anos. As crianças e os adolescentes são encaminhados pelo Conselho Tutelar e pela Vara da Infância e da Juventude do DF por se encontrarem em situação de risco social. No Larzinho, 09 crianças e adolescentes estão cadastrados para adoção. Desses, 06 são crianças e, 03 adolescentes. No momento, não há criança ou adolescente em estágio de convivência.

Quanto ao apoio e orientação sócio-familiar, a assistente social entrevistada informou que o acompanhamento é realizado por meio de visitas domiciliares e entrevistas na instituição de abrigo com as famílias das crianças e adolescentes, e tem como objetivo informar a Seção de fiscalização da VIJ/DF sobre a situação dessas famílias. A assistente social tem um projeto junto às voluntárias da congregação espírita, mediante o qual recolhe cestas básicas e materiais de construção para doar as famílias que reintegram seus filhos. Segundo ela, seu trabalho na instituição é quase voluntário, pois recebe o mínimo para atender o grande número de crianças e adolescentes, comparecendo à instituição uma vez por semana cumprindo oito horas semanais. 
Nesta instituição de abrigo as crianças são separadas em duas casas, uma para meninos e outra para meninas. As casas foram separadas, segunda a entrevistada, porque os meninos estavam apresentando comportamento sexual e as cuidadoras não sabiam lidar com este fato.

Informou, ainda, que as crianças e jovens freqüentam as escolas públicas próximas a instituição e que o tratamento de saúde é geralmente realizado nos hospitais da rede pública. $\mathrm{O}$ atendimento psicológico é feito por um profissional voluntário, que atende no ambiente da instituição, e o atendimento odontológico é realizado por dentistas voluntários em seus consultórios. A alimentação é confeccionada pelas cozinheiras da instituição.

Os recursos humanos contratados pela instituição são constituídos pelo seguinte pessoal: 2 cozinheiras, 1 assistente social, 1 lavadeira, 1 auxiliar de serviços diversos. A instituição conta, também, com um grupo de voluntários composto por pessoas da comunidade espírita que visitam e proporcionam passeios às crianças e adolescentes abrigados.

Quanto aos programas extracurriculares, o abrigo possui convênio com o SESC, onde as crianças e os adolescentes praticam natação e conta-se com voluntárias que contribuem com aulas de reforço escolar por ocasião das provas escolares.

Quanto às dificuldades encontradas pela instituição, a assistente social entrevistada declarou que todas as crianças e adolescentes abrigados possuem famílias; mas estas apresentam dificuldades para reintegrar suas crianças ou adolescentes, pois, em sua totalidade, não possuem condições financeiras para assumir os cuidados com os filhos. Muitas não tem endereço fixo, porque são, em maioria, moradores de rua ou residem em locais precários. 


\section{Capítulo IV}

\section{ANÁLISE DOS DADOS COLETADOS NA PESQUISA DE CAMPO}

Neste capítulo estão os resultados da análise das entrevistas com as assistentes sociais e uma psicóloga das instituições de abrigo do DF; com os profissionais da Seção de Adoção da VIJ/DF e dos dados recolhidos das "pastas especiais" sobre: o perfil das instituições pesquisadas, os motivos que levaram ao abrigamento crianças e adolescentes, as tentativas de reintegração familiar por parte das instituições de abrigo, os recursos para a convivência comunitária das crianças e adolescentes, e a percepção dos técnicos do judiciário quanto ao papel da adoção no acesso à convivência familiar.

Sumarizando, a pesquisa foi dividida em três fases para fins de organização e divisão do trabalho. Em julho de 2007 foi realizada a revisão de literatura; em agosto foram feitas as entrevistas com as profissionais das instituições de abrigo; em setembro foram recolhidos dados das "pastas especiais" de cinco crianças e cinco adolescentes cadastrados para adoção na VIJ/DF e, em outubro de 2007, foram realizadas entrevistas com dez profissionais da Seção de Adoção da VIJ/DF.

\subsection{Perfil das instituições pesquisadas}

Para tratar a questão do abrigamento é preciso considerar, em primeiro lugar, o perfil das cinco instituições pesquisadas e das crianças e adolescentes cadastrados para adoção que ali se encontravam.

O quadro a seguir apresenta uma síntese dos principais aspectos relativos à caracterização das instituições de abrigo. Como é possível notar, todas são instituições não governamentais, a maioria orientada por valores religiosos e dirigida por voluntários, e dependendo de recursos da comunidade e do Estado para o seu funcionamento. 
Quadro 1 - Perfil das entidades de abrigo pesquisadas

\begin{tabular}{|c|c|c|c|c|c|}
\hline Abrigos & ONG/Pública & $\begin{array}{c}\text { Vínculo } \\
\text { religioso }\end{array}$ & Fundação & Direção & $\begin{array}{c}\text { Recursos } \\
\text { Financiamento }\end{array}$ \\
\hline $\begin{array}{c}\text { Casa de } \\
\text { Ismael }\end{array}$ & $\begin{array}{c}\text { Não } \\
\text { governamental }\end{array}$ & Espírita & 1968 & voluntários & $\begin{array}{c}\text { Doações/ } \\
\text { público }\end{array}$ \\
\hline Nosso Lar & $\begin{array}{c}\text { Não } \\
\text { governamental }\end{array}$ & Espírita & 1974 & voluntários & $\begin{array}{c}\text { Doações/ } \\
\text { público }\end{array}$ \\
\hline $\begin{array}{c}\text { Aldeias } \\
\text { Infantis } \\
\text { SOS }\end{array}$ & $\begin{array}{c}\text { Não } \\
\text { governamental }\end{array}$ & $\begin{array}{c}\text { Sem } \\
\text { vínculo } \\
\text { religioso }\end{array}$ & 1968 & $\begin{array}{c}\text { Profissional } \\
\text { do quadro } \\
\text { do abrigo }\end{array}$ & $\begin{array}{c}\text { Doações/ } \\
\text { público }\end{array}$ \\
\hline $\begin{array}{c}\text { Casa do } \\
\text { Caminho }\end{array}$ & $\begin{array}{c}\text { Não } \\
\text { governamental }\end{array}$ & Espírita & 1987 & voluntários & $\begin{array}{c}\text { Doações/ } \\
\text { público }\end{array}$ \\
\hline $\begin{array}{c}\text { Chico } \\
\text { Xavier }\end{array}$ & $\begin{array}{c}\text { Não } \\
\text { governamental }\end{array}$ & Espírita & 1999 & voluntários & Doações \\
\hline
\end{tabular}

Elaboração própria

\subsection{Perfil das crianças e dos adolescentes cadastrados para adoção}

O quadro abaixo apresenta o perfil de cada uma das crianças e dos adolescentes pesquisados por meio das pastas especiais.

Quadro 2 - Perfil das crianças e dos adolescentes pesquisados

\begin{tabular}{|c|c|c|c|c|c|c|c|}
\hline \multicolumn{4}{|c}{ Crianças } & \multicolumn{4}{c|}{ Adolescentes } \\
\hline & Sexo & Idade & $\begin{array}{c}\text { Tempo de } \\
\text { abrigamento }\end{array}$ & & Sexo & Idade & $\begin{array}{c}\text { Tempo de } \\
\text { abrigamento }\end{array}$ \\
\hline 01 & M & 7 anos & 6 anos & 01 & F & 14 anos & 10 anos \\
\hline 02 & M & 7 anos & 4 anos & 02 & M & 14 anos & 10 anos \\
\hline 03 & F & 7 anos & 7 anos & 03 & F & 16 anos & 5 anos \\
\hline 04 & F & 10 anos & 6 anos & 04 & F & 17 anos & 11 anos \\
\hline 05 & M & 7 anos & 7 anos & 05 & F & 12 anos & 7 anos \\
\hline
\end{tabular}

Elaboração própria

No que diz respeito às 5 crianças e aos 5 adolescentes cadastrados para adoção atendidos nessas instituições, os dados levantados nas "pastas especiais" mostraram que um menino, com sete anos de idade, está abrigado há 6 anos; uma menina, com 14 anos de idade, há 10 anos; 1 menino de 7 anos de idade, há 4 anos ; 1 menino, de 14 anos de idade, 
há 10 anos; 1 menina de 7 anos, de idade, há 7 anos , 1 menina, de 16 anos de idade, há 5 anos; 1 menina, de 10 anos de idade, há seis anos; 1 menina, de 17 anos de idade, há 11 anos, 1 menino, de 7 anos de idade, há 7 anos; e 1 menina, de 12 anos de idade, há 7 anos. Percebe-se, assim, que apesar da medida de abrigo ser provisória, as crianças ou adolescentes permanecem, no mínimo, cinco anos abrigadas, recaindo maior incidência nos abrigados com idade mais elevada.

Curiosamente, todas essas crianças e esses adolescentes possuem famílias, mas estão impedidos judicialmente de ter contatos com elas, ou por terem perdido os vínculos familiares - devido à falta de visitas - ou porque a pobreza fez com que as famílias abrissem mão da responsabilidade de cuidá-los e mantê-los em seu seio. Observou-se, ainda, que todos freqüentam a escola, em sua maioria da rede pública de ensino, mas apresentam defasagem de série em relação à faixa etária (relação idade/série).

Algumas das crianças e adolescentes já passaram por outros abrigos: um menino passou por quatro instituições, após tentativas frustradas de reintegração ao núcleo biológico e a colaterais, e foi cadastrado para adoção, já tendo sofrido um mal sucedido estágio de convivência. Hoje, ele está com sete anos de idade.

\subsection{Motivos que levaram ao abrigamento de crianças e adolescentes}

Quanto aos motivos do abrigamento, verificou-se, mediante investigação nas pastas especiais, que predomina o risco social da criança ou do adolescente, pelos seguintes fatos: carência de recursos materiais da família/responsável, dependência química dos pais/responsáveis, seguidos de violência ou negligência, vivência de rua e falta de apoio das redes sociais.

Com esse estudo foi possível perceber que, antes do abandono, há uma série de situações que conduzem ao abrigamento, como a questão sócioeconômica e sua repercussão nas relações familiares, constituindo um fator determinante de violência e negligência contra crianças e adolescente que justificam a sua separação da família original.

Em um dos casos analisados ressalta a história de uma adolescente que foi abrigada aos dez anos de idade, ficou um ano na instituição e voltou a viver com a genitora, mas precisou ser abrigada novamente quando sua mãe perdeu o emprego. 
Situações como essas confirmam que a pouca atenção por parte do Estado às famílias pobres que possuem filhos sem condições de criá-los, ou de retirá-los dos abrigos contribui, de lado, para o aumento da condição de abrigamento, e, de outro, para a demora ou para o não resgate das crianças e adolescentes institucionalizados.

Nas entrevistas com as assistentes sociais da Seção de Adoção da VIJ/DF também evidenciaram-se, como aspectos da família biológica que levaram ao abrigamento de crianças ou adolescentes: a falta de estrutura, tanto financeira quanto emocional; a falta da rede de apoio, seja ela primária ou secundária; a dificuldade de acesso das famílias às políticas sociais de educação, saúde e habitação; a dificuldade do atendimento mais especializado para lidar com as questões afetivas, que levam a problemas na criação dos filhos.

Tanto as psicólogas como as assistentes sociais da Seção de Adoção afirmaram que a situação econômica das famílias tem influenciado para a institucionalização destas crianças e adolescentes. Portanto, nem sempre uma mãe possui capacidade e liberdade de escolha para entregar seu filho para adoção. Uma das psicólogas assim destacou a influência dessa situação para a adoção de crianças e adolescentes no Distrito Federal:

Certamente essa situação financeira das famílias tem influenciado muito. Nos casos de entrega de bebês também em que as genitoras são ouvidas e o tempo de abrigamento é mínimo, a maioria alega como motivo para a entrega a situação socioeconômica; de não ser capaz de cuidar por não ter condições socioeconômicas, o que afeta e compromete também o psicológico emocional dessa mãe.

È fato que o atendimento, a orientação e o apoio, um lugar para essa mãe ficar com esta criança, assim como a compreensão de sua situação psicológica, poderiam evitar que as instituições de abrigos brasileiras tivessem tantos filhos da solidão (WEBER e KOSSOBUDZKI, 1996).

O ECA dispõe sobre a proteção integral à criança e ao adolescente e em seu artigo $5^{\circ}$ preconiza: "Nenhuma criança ou adolescente será objeto de qualquer forma de negligência, discriminação e exploração, violência, crueldade e opressão, punido na forma da lei de qualquer atentado, por ação ou omissão, aos seus direitos fundamentais".

Por sua vez, o artigo 19 fala do direito da criança ser criada e educada no seio da sua família e do seu direito à convivência familiar e comunitária. Há também o princípio VI da Declaração Universal dos Direitos da Criança que chama atenção para que, salvo em 
circunstâncias excepcionais, não se deve separar a criança em tenra idade de sua mãe. Isso significa que existem leis e convenções para proteger a criança e a família, mas o que se constata é que as ações e as políticas de atendimento à família são paliativas e fragmentadas, com poucos recursos despendidos em programas isolados para diversos setores da pobreza.

Esses direitos das famílias estão sendo violados pela miséria e pela omissão da sociedade e do Estado, pois o que se observa são movimentos por parte dos parlamentares com o objetivo de definir prazos para a destituição do poder familiar, embora a falta de condições materiais não constitua motivo para tal. Percebe-se, ainda, por meio das entrevistas realizadas e da análise dos conteúdos das "pastas especiais" das crianças e adolescentes da VIJ/DF, que a realidade é bem diferente do que imaginam esses legisladores, a começar pelas relações familiares modificadas pela busca da sobrevivência, principalmente das mulheres que raramente possuem apoio do parceiro, da família ou do Estado para permanecer com seus filhos.

Não se pode negar que existem pais negligentes e irresponsáveis, os quais devem realmente perder o poder familiar, mas precisa-se primeiramente trabalhar para manter os vínculos de parentalidade/filiação entre crianças e adolescentes e suas famílias, como medidas para prevenir o abandono e para propiciar a reintegração familiar dessas crianças e adolescentes. Essa prática deveria ser comum, uma vez que a adoção deve ser a última alternativa.

Verifica-se, ademais, a partir dos relatos das assistentes sociais e da psicóloga entrevistadas nas instituições de abrigamento, que as famílias dessas crianças e adolescentes não apresentam redes sociais primárias de apoio. Sabe-se que, ao longo da vida uma pessoa constitui uma rede social primária composta por familiares, vizinhos, pessoas amigas, colegas de trabalho, organizações das quais participa (políticas, religiosas, sócio-culturais). Essa socialização começa na infância e nesse momento a rede de relacionamentos que a criança constrói a sua volta já é importante para o desenvolvimento de sua identidade individual e coletiva. Mas isso não é vivenciado pelas famílias das crianças abrigadas no Brasil.

Segundo uma das assistentes sociais da VIJ/DF, nos estudos psicossociais de algumas famílias que entregam seus filhos para adoção, percebe-se que os genitores vieram 
de famílias que não tiveram acesso à convivência familiar e comunitária, pois em sua maioria migraram do Norte e do Nordeste a procura de melhores condições de vida e de trabalho. E que durante esse percurso perderam o vínculo com a família extensa e não construíram uma rede social, terminando por reproduzir com seus filhos o mesmo abandono sofrido por eles e por seus pais.

$\mathrm{Na}$ entrevista com uma das psicólogas da Seção de Adoção, foi discutida a forma como se dá o cadastramento para adoção, na VIJ/DF, dessas crianças e adolescentes abrigados. Foi informado que quando a criança está abrigada sem ter contato com a família de origem, que parou de visitá-la e de procurar notícias dela, a instituição de abrigo comunica a VIJ/DF por meio de relatório. Além das informações do abrigo, a Comissão de Fiscalização da VIJ/DF faz estudo com as famílias dessas crianças/adolescentes com o objetivo não só de informar, mas também de dar sugestão para o cadastramento de adoção, quando a situação da família constituir risco a essas crianças ou adolescentes. A VIJ/DF repassa esses relatórios anexados ao processo da criança/adolescente para o Ministério Público, na Promotoria da Infância e da Juventude, que se pronuncia também sobre o cadastramento ou não dessas para adoção. Foi destacado que este cadastramento não é ainda a perda do poder familiar, que é retirado da família quando se dá o deferimento da adoção. Todo esse processo mostra uma preocupação com a integração da criança no seio familiar. Mas essa preocupação carece de bases estruturais para ser atendida.

\subsection{Tentativas de reintegração familiar por parte das instituições de abrigo}

Para avaliar a contribuição dos abrigos pesquisados tanto para a promoção do direito à convivência familiar e comunitária como para a reestruturação da família biológica de crianças e adolescentes, foram analisados, com base nos princípios estabelecidos nos artigos 92 e 94 do ECA, os vários aspectos que permitem indicar a adequação do atendimento prestado às diretrizes de reordenamento das práticas institucionais. Com relação à "convivência familiar" analisou-se o atendimento realizado pelos abrigos a partir de dois quesitos: preservação dos vínculos com a família biológica e apoio à reestruturação familiar. 
Quanto à "preservação dos vínculos familiares", foram consideradas as ações desenvolvidas pelas instituições: (a) ações de incentivo à convivência das crianças e adolescentes com suas famílias biológicas; e (b) o não-desmembramento de grupos de irmãos abrigados.

Observou-se que as instituições, em sua maioria, não mantinham informações como endereço atualizado, organização familiar, situação de trabalho e renda familiar sobre as famílias dos abrigados. Também não promovem visitas das crianças e dos adolescentes às suas famílias, apenas aguardam que apareçam no abrigo para visitá-los ou telefonam, quando possível, para que venham visitar os filhos.

Em relação à manutenção dos vínculos com os irmãos, as cinco instituições pesquisadas cumprem essa determinação, quando as cuidadores informam sobre brigas constantes entre eles, mas, apenas colocando em casas diferentes dentro no próprio abrigo.

No caso do apoio à reestruturação familiar, estes envolvem aspectos complexos, relacionados a fatores difíceis de serem resolvidos em curto prazo, como por exemplo, o desemprego, a capacitação e a dependência química, que demandam muito mais da coordenação das políticas públicas do que das instituições de abrigo. No entanto, essas instituições poderiam realizar programas ou projetos para valorizar as famílias, e também encaminhá-las para a inserção na rede de proteção social disponível, além orientá-las para procurar o órgão competente para serem inseridas nas políticas públicas. Verificou-se que das cinco instituições investigadas em apenas uma a assistente social realiza reuniões mensais com estas famílias com o objetivo de orientá-las sobre a importância de visitar com freqüência seus filhos para manter o vínculo familiar.

Buscou-se verificar nas instituições pesquisadas o "apoio à reestruturação familiar" promovida por ações como: (a) visitas domiciliares às famílias dos abrigados; (b) acompanhamento social das famílias; (c) organização de reuniões ou grupos de apoio para esses familiares; (d) encaminhamento das famílias para inserção em programas oficiais ou da comunidade de auxílio e proteção à família. As instituições em sua maioria não realizam todas essas ações em conjunto, mas apenas algumas ações.

As ações do abrigo mostraram-se extremamente focalizadas e dispersas, atingindo apenas alguns indivíduos ou grupos familiares específicos, além de dependerem unicamente de iniciativas voluntárias, não constituindo um trabalho sistematizado no 
formato de um programa ou projeto. Essas iniciativas não têm vínculo algum com propostas estatais de políticas. Por exemplo: a psicóloga relatou que reúne pessoas da comunidade espírita, as quais são voluntárias no abrigo e recolhem cestas básicas, para doar às famílias. Uma assistente social de outro abrigo revelou que conseguiu um lote com o Governo do Distrito Federal e construiu, com a ajuda de voluntários do abrigo, três cômodos para abrigar e reintegrar uma mãe moradora de rua que sempre visitou os filhos (declarou que a mãe não aceitou retirar as crianças e mudar para a casa, pois recolhia papéis e lixo reciclável em outra região administrativa, e que não poderia trabalhar em outro lugar, distante de seus conhecidos). Outra assistente social relatou que um grupo de estagiários do abrigo realiza um projeto com as mães sociais que visa à preparação para o desligamento da criança, seja para reintegração ou adoção (o grupo de estagiários também realiza palestras sobre os problemas causados pelo alcoolismo e a drogadição).

Percebe-se, portanto, que os trabalhos de reintegração familiar realizados pelos abrigos têm caráter pontual e passivo, pois os profissionais esperam que as famílias busquem a instituição com o objetivo de reatar os laços com a criança ou o adolescente. $\mathrm{O}$ abrigo com os parcos recursos, tanto financeiros quanto profissionais, se exime da responsabilidade de desenvolver atividades de reintegração, realizando ações assistencialistas que, além de não promover a emancipação dessas famílias, também não contribui para o resgate de seus filhos.

Observou-se com essa pesquisa que os abrigos não possuem profissionais em número suficiente para dar suporte com pesquisas, visando localizar as famílias desaparecidas dessas crianças e adolescentes, assim como encaminhá-las para as redes sociais de atendimento, seja para colocação em programas oficiais de capacitação, geração de renda e introdução do mercado de trabalho, seja para tratamento de saúde.

Uma das profissionais da VIJ/DF afirmou na entrevista que, em alguns abrigos, as assistentes sociais demonstram boa vontade, mas às vezes esbarram na dificuldade do grande número de crianças e da quantidade de trabalho a realizar na instituição. Citou que uma assistente social de uma das instituições de abrigamento declarou que existem famílias que ficam aguardando de um a dois anos para serem visitadas pelo profissional, que não consegue dar conta da alta demanda da instituição, principalmente porque sua carga horária na instituição é de oito horas semanais. O baixo salário a obriga a ter um segundo emprego 
para suprir suas necessidades. Segundo essa assistente social, há famílias que visitam seus filhos no abrigo e então são entrevistados e consultados sobre a possibilidade de recebê-los de volta.

A psicóloga de um abrigo destacou, em sua fala, o fato de ser a única profissional técnica no abrigo, o que a sobrecarrega em suas funções.

$\mathrm{Eu}$ realizo com muita freqüência visitas domiciliares, atendimento a essas famílias, e o que a gente pode ajudar, porque o abrigo vive muito de doação, mas tenta-se ajudar principalmente aquelas famílias em que está se tentando a reintegração e que se percebe a possibilidade... por questões econômicas, sociais, governo, falta de rede de apoio, rede de tudo, a gente tenta dar uma cesta básica minimamente para ver essa adequação, e vai fazer visita para ver como é essa criança com essa família. No momento é o que a gente ta podendo fazer com essas famílias. A demanda é muito grande, muito grande, é muita criança. Não tem assistente social, nem outro psicólogo.

\subsection{Recursos para a convivência comunitária das crianças e dos adolescentes}

Em relação à promoção do direito à convivência comunitária para os abrigados, antes do ECA, as atividades como educação, atenção à saúde, lazer e serviços eram desenvolvidas dentro das instituições. Com o ECA o abrigo passou a ser medida de proteção, não de privação da liberdade, então é recomendada a participação na vida da comunidade, que deve ser concretizada, pela garantia de acesso dos abrigados às políticas básicas e aos serviços oferecidos para a comunidade, pois desta forma as crianças e os adolescentes terão acesso a atividades externas de lazer, esporte, religião e cultura, interagindo com a comunidade.

A pesquisa nos abrigos do DF mostrou que essas instituições procuram inserir os abrigados nesses recursos da comunidade, mas em nenhuma das comunidades pertencentes há disponibilidade de ensino de capacitação e profissionalização para os adolescentes. Em duas instituições, Casa de Ismael e Nosso Lar, existe o Programa Adolescente Aprendiz, o qual envolve o trabalho aprendiz nos bancos do DF, mas não capacita para atividades fora do universo bancário, o que dificulta posteriormente a inclusão no mercado de trabalho, já que a maioria dos bancos realiza concursos em que os pretendentes necessitam de alto grau de escolaridade.

A participação comunitária no abrigo se dá por meio dos trabalhos voluntários no âmbito de serviços complementares, realizados por estudantes estagiários, professores de 
reforço escolar, recreadores, orientadores espirituais/religiosos, médicos, dentistas e psicólogos.

Cabe mencionar que essas instituições enfrentam inúmeras dificuldades para o cumprimento de suas atribuições, considerando que além das restrições financeiras, materiais e de recursos humanos, ainda é presente entre as entidades de abrigo a percepção de que, havendo problemas familiares, seja ele de qualquer ordem, o melhor lugar para crianças e adolescentes é a instituição, pois acreditam que "terão melhores condições de vida". Esse fato faz com que os abrigos se apropriem dessas crianças e adolescentes e não se preocupem com a promoção de seu direito à convivência familiar junto a sua família biológica, quando não for possível em família substituta, além da convivência comunitária.

\subsection{A percepção dos técnicos judiciários quanto ao papel da adoção no acesso à convivência familiar}

Compreendendo o processo de negligência social que a família brasileira marginalizada sofre atualmente, procurou-se investigar a percepção dos profissionais da Seção de Adoção da VIJ/DF, quanto à importância da manutenção das crianças e adolescentes em seus núcleos biológicos, assim como observar se as dificuldades encontradas pela família biológica no processo de reestruturação, faz com que a adoção seja na opinião desses profissionais, hoje, realmente a única alternativa das crianças e adolescentes conviverem em uma família.

Uma das assistentes sociais da Seção de Adoção ressalta:

\footnotetext{
$\mathrm{Na}$ condição de filho, a adoção é sim a única alternativa. Olhando a questão da realidade de crianças e adolescentes que estão crescendo nos abrigos, eles crescem sem uma família e eles vão sair de lá em busca de construir a sua própria, isso em sua minoria, quando isso for possível. Então, na condição das crianças/adolescentes abrigados, talvez a adoção seja mesmo a única alternativa para eles poderem ter um convívio na família, uma vez que o abrigo não consegue fazer a reintegração.
}

Outra assistente social colocou que os casos que vão para adoção na VIJ/DF são a última e também única alternativa, no sentido de que a família biológica deixa de ser uma opção. Então, na verdade, a única opção que essa criança/adolescente tem para estar numa família é a adoção. 
Em relação às psicólogas, uma delas relatou que em algumas situações não são esgotadas todas as possibilidades dessa criança estar em seu núcleo biológico, porque houve algum impedimento para isso, como por exemplo:

\begin{abstract}
Uma mãe que está escondendo a gestação de toda a família e quer entregar essa criança para adoção, dificilmente a justiça vai revelar esse segredo para a família e ver se alguém dessa família quer ficar com essa criança. É uma situação e tem várias que necessitam ser estudadas em suas peculiaridades. Nesse caso, estaria prevalecendo o direito da mãe? Não sei, porque também, se é difundido na sociedade que eu não posso fazer uma entrega anônima, sem minha família saber, pode ser que isso leve as mães a optarem por interromper a gravidez, porque não têm a oportunidade de entregar essa criança no anonimato. Então são questões bem complexas. Eu acho o critério do ECA muito adequado, só quando não existir possibilidade da criança permanecer em seu núcleo biológico. Agora, esse critério em alguns casos específicos gera discussões e dúvidas. Será que, se ligar para avó da criança, ela vai dizer "eu quero"? Talvez sim, mas é uma situação difícil de lidar.
\end{abstract}

Esses fatos reforçam o que a procuradora do Estado de São Paulo, Flávia Piovizan discute sobre a dificuldade, não só da sociedade, mas também dos legisladores e da justiça, em lidar com os direitos da criança e do adolescente, e de conhecer mais a fundo a sua legitimidade. Pois, o parto anônimo nega o nome dos pais biológicos ao nascituro, ferindo um direito civil básico, previsto na Constituição Federal vigente, que é "o direito à identidade".

Considerando o conteúdo das entrevistas das profissionais das instituições de abrigo, das profissionais da Seção de Adoção da VIJ/DF e os dados das fichas das crianças e adolescentes cadastrados para adoção, verifica-se que as dificuldades encontradas para reestruturar as famílias dessas crianças e adolescentes contribuem de forma decisiva para a sua disponibilização para adoção. 


\section{Considerações finais}

A partir desta pesquisa nas instituições de abrigo do DF, na Seção de Adoção da VIJ/DF e nas pastas especiais de crianças e adolescentes abrigados e cadastrados para adoção, foi possível conhecer as razões que levaram a VIJ/DF a cadastrar para adoção crianças e adolescentes abrigadas nas instituições do Distrito Federal.

Apesar do ECA, em seu Art. 23, estabelecer que a falta ou a carência de recursos materiais não constitui motivo suficiente para a perda ou suspensão do poder familiar, as razões encontradas pela pesquisa confirmaram a hipótese anteriormente levantada de que as famílias não encontram alternativas para cuidar bem de seus filhos, que não na adoção. As crianças e os adolescentes são deixados nas instituições de abrigamento, enquanto sua família não consegue ser incluída em programas oficias de auxílio, para acessar recursos que visam à reestruturação.

Nos abrigos pesquisados encontrou-se um quadro preocupante: as ações dispensadas às famílias com vista à reestruturação são dispersas, não têm caráter coletivo e não possuem critérios de elegibilidade. São ações mais que pontuais, pois não chegam a atingir um grupo, mas apenas indivíduos ou núcleos familiares específicos.

Constatou-se que o procedimento realizado por estas instituições para reintegrar as crianças e adolescentes a suas famílias é falho, principalmente no que se refere ao trabalho da transformação de sua realidade, que permita o exercício das funções parentais. $\mathrm{O}$ sofrimento experimentado pelas famílias que entregam seus filhos para adoção ou por aquelas que os vêem em situação de abrigamento em geral tem relação direta com o sofrimento passado por seus ascendentes na infância. Isso foi e é corroborado pela falta de assistência por parte do Estado

Essas famílias são vítimas de um Estado capitalista neoliberal que provoca um desarme social e político para a maioria dos cidadãos. O Estado se desresponsabiliza quanto ao que é de interesse público, transferindo para a sociedade civil suas obrigações.

No que diz respeito à instância jurídica, registra-se que a falta de profissionais no judiciário e na VIJ/DF prejudica o acompanhamento das famílias, já que o número de processos distribuídos para cada profissional técnico não permite a realização de projetos com a demanda da Seção de Adoção. A saída encontrada é o estabelecimento de convênios 
ou terceirizar os serviços. Um exemplo claro dessa tendência foi a criação da rede social “Anjos do amanhã", São ações voluntárias que envolvem competências, habilidades e recursos financeiros, mas também são empregos que deixam de ser efetivados em nome de uma responsabilidade retirada do Estado e imposta à sociedade civil.

Essas constatações reafirmam a necessidade de se estancar a flexibilização e a desregulamentação das leis trabalhistas, que contribuem para o aumento do desemprego estrutural e do trabalho informal.

Os fatos relatados nesta pesquisa constituem um desafio para o Serviço social na busca pela garantia dos direitos sociais dessas famílias, num país onde imperam níveis assustadores de pobreza e miserabilidade.

O ideal seria que adoção existisse apenas para crianças que perderam suas famílias em catástrofes ou para aquelas mães que não desejaram ter filho ou explicitem à justiça a falta de condições emocionais para estar com a criança.

Esse tema interessa ao Serviço Social, uma vez que representa um exemplo extremo do abandono do Estado e da falta de políticas específicas e de uma rede de atendimento adequada.

Nesse sentido é urgente procurar a efetivação dos ordenamentos jurídico-políticos, cobrando-se das instâncias governamentais responsáveis as ações para a ampliação e a consolidação da cidadania e da democracia no país. Cabe aos assistentes sociais uma reflexão sobre como planejar ferramentas para que as famílias consigam exercer sua cidadania e atinjam as condições para exercerem os cuidados com seus filhos.

Que a igualdade e a justiça sejam os princípios na busca de uma sociedade que tenha acesso a políticas de proteção social capazes de modificar a realidade verificada. 


\section{REFERÊNCIAS BIBLIOGRÁFICAS}

ARIÈS, Philippe. História social da criança e da família. 2. ed. Traduzido por Dora Flaksman. Rio de Janeiro : Guanabara, 1981.

BADINTER, Elisabeth. Sobre o abandono de crianças escravas. In: BADINTER, Elisabeth. Um Amor conquistado: o mito do amor materno. $3^{\text {a }}$ ed. Rio de Janeiro, 1985.

BRASIL. Lei 8.069, de 13 de julho de 1991. Estatuto da Criança e do Adolescente (ECA). Brasília, 1991.

BRASIL, Lei 3.071/1916, Código Civil. 1916.

BRASIL, Lei no 3.133/1957, Código Civil 1957.

BRASIL, Lei nº4. 655/1965, Código Civil 1965.

BRASIL, Lei nº 6.697/1979 (instituiu o Código de Menores).

BRASIL, Lei n 10.406/2002 - Código Civil de 2002.

CIVILETTI, Maria Vitória Pardal. "O cuidado às crianças pequenas no Brasil Escravista". In Cadernos de Pesquisa. São Paulo, no 76, pp. 31-40, fev./91. jan./92, Nova Fronteira, 1985.

COSTA, Jurandir Freire. A partir de uma leitura feita de Foucault. Ordem médica e norma familiar. Rio de Janeiro, Edições Graal, 1979, Cap. III, p.49.

CORREIO BRAZILIENSE. Mães Anônimas. 14 out 2007, p. 13. Brasília, 2007.

DINIZ, J. S. A adoção: notas para uma visão global. In: FREIRE, F.(org.). Abandono e adoção - contribuições para uma cultura da adoção II. Curitiba, Terre dês Hommes, 1994.

FALEIROS, Vicente de Paula. (Coord). (1995). Crianças e Adolescentes, pensar e fazer. Brasília: CEAD-UNB/FCBIA

FONSECA, Claudia. Caminhos da adoção. São Paulo, Cortez, 1995

FREIRE, Fernando. (org) Abandono e adoção - contribuição para uma cultura de adoção. Curitiba: Gráfica Vicentina, 1991

GIL, Antonio Carlos. Métodos e técnicas de pesquisa social. São Paulo: Atlas, 1999.

IPEA/DISOC (2004/2005). Levantamento Nacional de Abrigos para Crianças e Adolescentes da Rede SAC. 
LAKATOS, Eva Maria; MARCONI, Marina de Andrade. Metodologia do trabalho científico. São Paulo: Atlas, 1991.

MARCÍLIO, Maria Luiza. A roda dos Expostos e a criança abandonada na História do Brasil. 1726-1950. História Social da Criança Abandonada. São Paulo: Hucitec, 1998.

MINAYO, Maria Cecília de Souza. O desafio do conhecimento: Pesquisa qualitativa em saúde. São Paulo/Rio de Janeiro:Hucitec-ABRASCO, 1992.

MINAYO, Maria Cecília da Souza Minayo (Org.) Pesquisa social: Teoria, método e criatividade, $7^{\mathrm{a}}$ ed. Rio de Janeiro: Vozes, 1994.

MOTTA, Maria Antonieta Pisano (2001). Mães Abandonadas: a entrega de um filho em adoção. São Paulo: Cortez.

MUCHIELLI, A. Que sais-je? In: Lês métodes qualitatives. Paris, Presses Universitaires de France, 1991.

OLIVEIRA, Márcia Gomes da Silva. O projeto de apadrinhamento afetivo nas casaslares Nossa Senhora do Carmo e São João da Cruz: práticas vivenciadas - 1998 a 2001. Monografia para obtenção do título de Especialista em Metodologia de Atendimento à Criança e Adolescente em Situação de Risco. Centro de Ciências de Educação, Universidade do Estado de Santa Catarina, Florianópolis, 2002.p. 14.

PASSETTI, Edson. Crianças carentes e políticas públicas. In: História das crianças no Brasil. Mary Del Priore (org.). 2a ed. São Paulo: Contexto, 2000, pgs. 347-375.

PEREIRA, J. M. F. \& SANTOS, Manoel Antônio dos (1998). O Enfoque psicológico da adoção: Revisão da literatura. Em R.C. Labate (Org.), Caminhando para a assistência integral (pp. 225-246). Ribeirão Preto: Scala.

PORTO, Ângela de Araújo. As Artimanhas de Esculápio: crença ou ciência no saber médico. Niterói, Instituto de Ciências Humanas e Filosofia, Universidade Federal Fluminense, 1985, p.17. (Dissertação de Mestrado)

TRINDADE, Judite Maria Barboza. Rev. Bras. Hist. vol.19, n.37 São Paulo, Sept. 1999 VARGAS, MARLIZETE MALDONADO. Adoção Tardia: da família sonhada à família possível - São Paulo: Casa do Psicólogo, 1998.

VENÂNCIO, Renato Pinto (1999). Famílias Abandonadas: assistência à criança de camadas populares no Rio de Janeiro e em Salvador - Séculos XVIII E XIX. Campinas: Papirus. 
WEBER, Lídia Natalia Dobrianskyj et. Al. Institucionalização e Abandono de crianças no Paraná. Humanas, UFPR, Curitiba. 1996

WEBER, Lídia Natalia Dobrianskyj \& KOSSOBUDZKI, Lúcia Helena Milazzo. Filhos da

Solidão: institucionalização, abandono e adoção. Curitiba, Governo do Estado do Paraná, 1996. 